\begin{tabular}{c|c|c}
\hline \hline & MARINE ECOLOGY PROGRESS SERIES \\
Vol. 268: 245-264, 2004 & Mar Ecol Prog Ser & Published March 9 \\
\hline \hline
\end{tabular}

\title{
Foraging ecology of the early life stages of four sympatric shark species
}

\author{
Dana M. Bethea ${ }^{1,3, *}$, Jeffrey A. Buckel ${ }^{1}$, John K. Carlson ${ }^{2}$ \\ ${ }^{1}$ Department of Zoology, North Carolina State University, Center for Marine Sciences and Technology, 303 College Circle, \\ Morehead City, North Carolina 28557, USA \\ ${ }^{2}$ Southeast Fisheries Science Center, National Marine Fisheries Service, NOAA, Panama City Laboratory, \\ 3500 Delwood Beach Road, Panama City Beach, Florida 32408, USA \\ ${ }^{3}$ Present address: Southeast Fisheries Science Center, National Marine Fisheries Service, NOAA, Panama City Laboratory, \\ 3500 Delwood Beach Road, Panama City Beach, Florida 32408, USA
}

\begin{abstract}
Sharks may have an important role in marine ecosystems in relation to populations of fish and invertebrates at lower trophic levels. Fishery management plans stress the need for an ecosystem approach, but few quantitative studies on the foraging ecology of sharks have been published. Stomach contents and catch data of early life stages of Atlantic sharpnose Rhizoprionodon terraenovae, blacktip Carcharhinus limbatus, finetooth Carcharhinus isodon, and spinner sharks Carcharhinus brevipinna taken from fishery independent surveys in Apalachicola Bay, Florida, USA, were examined to test for overlap in resource use. Young-of-the-year Atlantic sharpnose sharks were found to feed mainly on shrimp, juveniles on sciaenids, and adults on clupeids. Young-of-the-year blacktip sharks were found to feed mainly on sciaenids, whereas juveniles fed on clupeids. The primary prey of young-of-the-year and juvenile finetooth and spinner sharks was clupeids. Eight of 10 prey size-selectivity tests showed neutral selection. Compared to relative prey sizes published for teleost piscivores, Atlantic sharpnose and finetooth sharks consume relatively small-sized prey while blacktip sharks consume relatively large prey. Regardless of maturity state and species, diet overlap was high for species-life stage combinations that are similar in size; however, species-life stages did not show significant habitat overlap. Prey categories shared by similar-sized species may not be limiting, although shark species may have alleviated competition pressure by partitioning the resource of time or space.
\end{abstract}

KEY WORDS: Foraging ecology · Resource partitioning • Competition · Prey size-predator size relationships · Apalachicola Bay · Rhizoprionodon terraenovae ' Carcharhinus limbatus . Carcharhinus isodon · Carcharhinus brevipinna

Resale or republication not permitted without written consent of the publisher

\section{INTRODUCTION}

Sharks are considered top predators and may have an important role in the regulation of marine ecosystems at lower trophic levels (Cortés 1999, Stevens et al. 2000, Schindler et al. 2002). As such, their removal from coastal ecosystems could cause a trophic cascading effect within the remaining community, possibly altering the abundance of lower trophic, fisherytargeted species (Jennings \& Kaiser 1998). Given this, it is important that accurate biological and ecological information be obtained to aid in assessing and monitoring of populations of sharks and their prey. The current Fishery Management Plan for sharks (NMFS 1999a) gives little consideration to ecosystem function because there is little quantitative species-specific data on competition, predator-prey interactions, and habitat requirements of sharks (NMFS 1999b).

Nursery areas are hypothesized to provide substantial food resources in a low predation environment (Branstetter 1990, Simpfendorfer \& Milward 1993); however, a proposed disadvantage of several species 
utilizing the same nursery area is the increased chance of competition among juveniles for food and habitat resources. Increased competition for resources within the nursery area may influence juvenile mortality by affecting growth rate and spatial distribution. For example, Heupel \& Simpfendorfer (2002) found that juvenile blacktip sharks in Terra Ceia Bay, Florida, were most susceptible to mortality in the first $15 \mathrm{wk}$ of life (neonate and young-of-the-year life stages).

Apalachicola Bay, Florida, is a proposed nursery area for several species of sharks in the Gulf of Mexico (Carlson \& Brusher 1999). Beginning in spring, juvenile blacktip, finetooth, and spinner sharks recruit to the Apalachicola Bay system. In late May to early June, adult sharks move into the bay system to give birth. Young-of-the-year and juvenile Atlantic sharpnose, blacktip, finetooth, and spinner sharks are present in this area by the end of June and all species generally remain within this area until fall when they emigrate offshore (Carlson \& Brusher 1999).

The purpose of this study was to investigate the foraging ecology of early life stages of Atlantic sharpnose, blacktip, finetooth, and spinner sharks in Apalachicola Bay, Florida, to determine levels of resource overlap. Here, we (1) describe and quantify the diet of each shark species-life stage, (2) calculate diet overlap for shark species-life stage combinations, (3) calculate habitat overlap for shark species-life stage combinations using fishery-independent catch

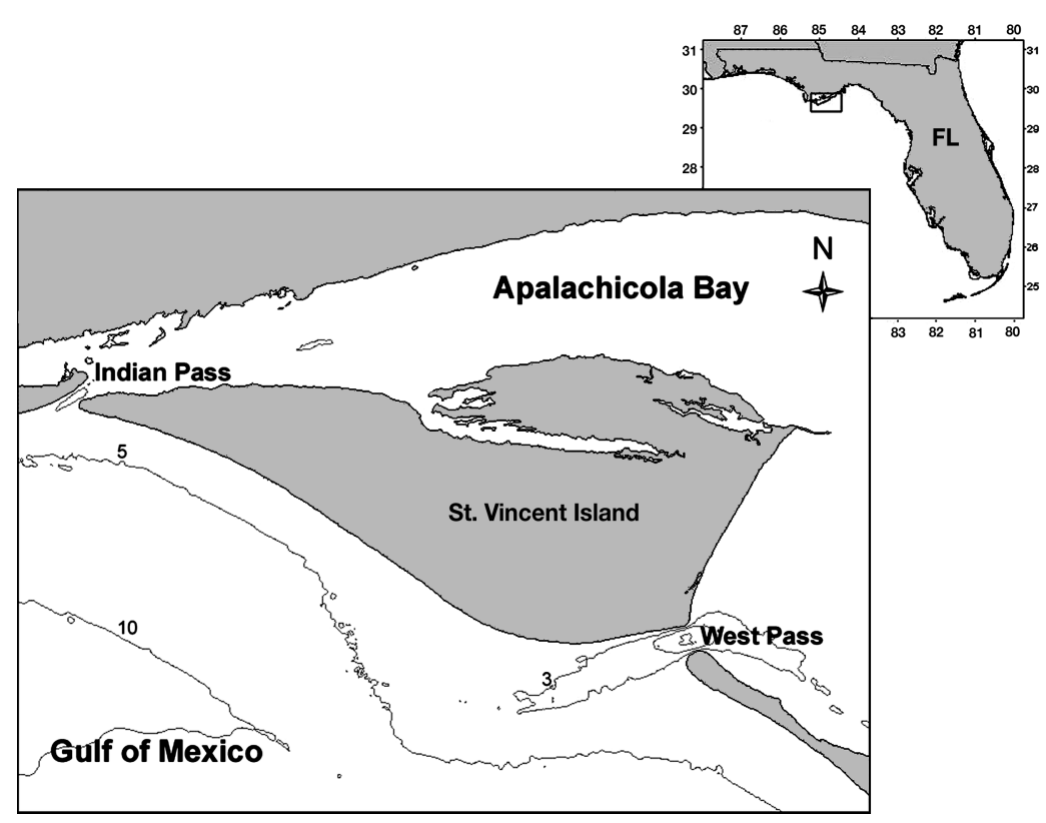

Fig. 1. Map of Apalachicola Bay, Florida. Sharks and potential prey items were taken from fishery-independent surveys conducted by the National Marine Fisheries Service (NMFS) on the Gulf of Mexico side of St. Vincent Island, Florida, at the southwest end of the Apalachicola Bay system between Indian Pass and West Pass from April through October 1999 to 2002. Contour lines are depth (m) data, and (4) examine prey size-predator size relationships for shark species.

\section{MATERIALS AND METHODS}

Feeding habits. Collection of samples: Sharks and potential prey items were taken from fisheryindependent surveys conducted at the southwest end of the Apalachicola Bay system from April through October of 1999 to 2002 (Fig. 1).

A 186 m (558 ft) multi-panel gillnet (following Carlson \& Brusher 1999) was set at random stations, anchored at both ends, allowed to soak for 0.75 to $1.0 \mathrm{~h}$ in depths ranging from 3 to $10 \mathrm{~m}$, and then retrieved and cleared of catch. For each shark sampled, fork length (mm), weight $(\mathrm{kg})$, sex, and life stage were determined. The life stage of each shark species was assessed and categorized as: (1) young-of-the-year (i.e. age $0+$ ), characterized by either an open or healed but visible umbilical scar; (2) juvenile, characterized as not yet being mature; or (3) adult. For males, adults were characterized as having well-developed testes, hardened claspers, and the ability to spread the rhipidion (Pratt 1988). Adult females were characterized as having developed oocytes or the presence of pups. Ultimately, no sharks greater than $1100 \mathrm{~mm}$ fork length (FL) ( 1200 mm total length, TL) were included in this study. In the field, stomachs were extracted, placed in labeled plastic bags, stored on ice, and frozen upon returning to the laboratory. Occasionally, whole sharks were iced and stomachs extracted in the laboratory. Potential prey items collected from the $186 \mathrm{~m}$ gillnet were placed on ice in the field, stored on ice at $4^{\circ} \mathrm{C}$ overnight, and examined the following day.

Preliminary analysis of stomach contents from spring and summer 2001 showed that sharks took considerably smaller prey than was collected in the $186 \mathrm{~m}$ gillnet. To better sample potential prey size distributions in the field, a $100 \mathrm{~m}$ (300 ft) multi-panel gillnet with variable stretch-mesh sizes ranging from $2.5 \mathrm{~cm}\left(1.0^{\prime \prime}\right)$ to $7.6 \mathrm{~cm}\left(3.0^{\prime \prime}\right)$ in intervals of $2.5 \mathrm{~cm}\left(1.0^{\prime \prime}\right)$ was used in the system during late-summer and fall 2001 and throughout 2002. The $100 \mathrm{~m}$ gillnet was anchored at both ends, set in the same general location as the $186 \mathrm{~m}$ gillnet, allowed to soak for 2.0 to $5.0 \mathrm{~h}$, and then retrieved. Sharks caught in the $100 \mathrm{~m}$ gillnet were cleared from the net and stored as previously described. 
After clearing sharks, the $100 \mathrm{~m}$ gillnet was stored on ice in a container below deck until returning to the laboratory where it was cleared of the remaining catch. Potential prey items were stored as previously stated and examined the following day.

Upon further investigation of stomach contents from 2001 and early-summer 2002, epibenthic prey were found to be important in the diets. Because gillnets were inadequate in sampling epibenthic prey, a $6.7 \mathrm{~m}$ $(21 \mathrm{ft})$, semi-balloon otter trawl was used to sample prey sizes in the system during summer and fall 2002. The trawl was towed parallel to the shore at 2 knots for $10 \mathrm{~min}$ at depths of approximately $3 \mathrm{~m}$. Catch was cleared from the trawl and potential prey were stored as previously described.

Further, the Florida Marine Research Institute (FMRI) Fisheries-Independent Monitoring program provided additional prey size data for Brevoortia spp. and Micropogonias undulatus from western Apalachicola Bay for June, July, and August 2001 (T. Tuckey, FMRI, pers. comm.). FMRI samples were collected using an otter trawl and beach seine (http:// floridamarine.org/features/view_article.asp?id=20074).

Laboratory processing: Stomachs were thawed for $1 \mathrm{~h}$, opened, and rinsed with water over a $595 \mu \mathrm{m}$ $(0.0234 ")$ sieve. Prey items found in the stomachs were identified to the lowest possible taxon, counted, and weighed. When possible for teleost prey items, FL or TL were measured directly. When partial teleost prey or whole but digested teleost prey were present and length could not be measured directly, the partial prey measurements of body depth (BD), caudal peduncle depth (CPD), snout to operculum length (SOL), and/or total otolith weight (TOW) were measured and predictive equations (detailed below) were used to estimate original FL or TL. Digestion of otoliths can affect both the identification of prey species and reconstruction of original prey size (Jobling \& Breiby 1986). Otoliths taken directly from stomachs were examined for digestion (e.g. smooth edges). Otoliths that showed signs of digestion were not used to reconstruct prey size.

Potential prey items collected in the gillnets and trawl were separated, counted, weighed, and measured. FL or TL, BD, CPD, and SOL were measured. Sagittal otoliths were removed and TOW measured. Predictive equations were constructed relating potential prey length with $\mathrm{BD}, \mathrm{CPD}, \mathrm{SOL}$, and TOW using least-squares regression analysis (Zar 1999, p. 326-333). Equations were generated for gafftopsail catfish Bagre marinus, menhaden Brevoortia spp., sand seatrout Cynoscion arenarius, Atlantic croaker Micropogonias undulatus, and star drum Stellifer lanceolatus. These 5 prey species made up a significant portion of available prey and diets of sharks in the Apalachicola Bay system.
Analysis of stomach contents: With the exception of finetooth and spinner sharks, shark diet was assessed by individual species and life stage. Diets of finetooth and spinner shark life stages were combined for young-of-the-year and juvenile due to low sample size and the consistency of diet with ontogeny. In all analyses, finetooth and spinner shark life stages will be referred to as juvenile. Diets of each shark species-life stage were quantified using 3 indices: percent by number $(\% \mathrm{~N})$, percent by weight $(\% \mathrm{~W})$, and percent by frequency of occurrence $(\% \mathrm{O}) . \% \mathrm{~N}$ was calculated as the number of each prey type divided by the total number of prey items in the stomachs. \%W of a prey type was calculated as the total weight of each prey type divided by the total weight of prey items in the stomachs. $\% \mathrm{O}$ of a prey type was calculated as the number of stomachs containing the prey type divided by the total number of stomachs containing food. A fourth index, the index of relative importance (IRI), was calculated as the sum of the $\% \mathrm{~W}$ and $\% \mathrm{~N}$ multiplied by $\% \mathrm{O}$ for each prey type $[I R I=\% O(\% N+\% W)]$; the IRI for each prey type was divided by the total IRI for all prey items to get the index of relative importance on a percent basis (\%IRI; Cortés 1997).

To facilitate diet comparisons and standardize diet overlap analysis among the species-life stages, identifiable prey items were also categorized into 6 major prey categories (PC): (1) Family Clupeidae, (2) other pelagic teleosts, (3) Family Sciaenidae, (4) other epibenthic teleosts, (5) crustaceans, and (6) other invertebrates. The IRI on a percent basis was also computed for the 6 major prey categories (IRI\% ${ }_{\mathrm{PC}}$ ).

Cumulative prey curves were constructed a posteriori for all species-life stages to determine if an adequate number of stomachs had been collected to accurately describe diets (Ferry \& Cailliet 1996). The order in which stomachs were analyzed was randomized 10 times and the cumulative number of new prey items was counted for each randomization. The total number of stomachs analyzed was plotted against the mean number of new prey items that were found in the stomachs. It has been suggested that the presence of angiosperms in shark stomachs is reflective of benthic feeding habits (Cortés \& Gruber 1990, Cortés et al. 1996). For this reason, these items were considered incidental to prey capture and were not counted as unique prey items. All other identifiable prey items were counted as unique. When the curve reached a stable asymptote, then the number of stomachs analyzed was considered sufficient in describing dietary habits.

During a $1 \mathrm{~h}$ soak, sharks could be attracted to and feed on items already caught in the gillnets. To test for net-feeding bias in the diet index estimates, identifiable prey taken from stomachs were classified as fresh or digested. Fresh prey had no signs of digestion. 
Digested prey were considered anywhere from partially digested (e.g. starting to lose scales or fins) to well digested (e.g. several small pieces remaining). $\% \mathrm{O}$ of the 6 major prey categories was compared between fresh and digested categories for all shark species-life stages. If the $\% \mathrm{O}$ of fresh prey items was similar to $\% \mathrm{O}$ of digested prey items, then net-feeding was likely minimal and had little effect on diet index estimates (Buckel et al. 1999).

Dietary overlap. Diet overlap matrices were constructed using Schoener's overlap index. The index:

$$
\alpha=1-0.5\left(\sum_{i=1}^{n}\left|p_{i j}-p_{i k}\right|\right)
$$

determines overlap $(\alpha)$, where $p_{i j}=$ the proportion of the ith resource (prey category) used by species $j$, and $p_{i k}=$ the proportion of the $i$ th resource used by species $k$. Overlap index values range from 0 (no overlap) to 1.0 (complete overlap), and values equal to or greater than 0.6 are considered 'biologically significant' (Pianka 1976). Dietary overlap was calculated using Ecological Methodology v 5.1 software ${ }^{1}$. All resources were assumed equally abundant and resource states were presented as IRI\% $\%_{\text {PC }}$.

Diet can be affected by changes in prey availability. Therefore, diet overlap was calculated by month (May to October) for 2001 and 2002. To avoid low sample sizes, overlap analysis was restricted to months when at least 3 stomachs contained identifiable prey for at least 2 of the 7 shark species-life stages. Months that met the requirements in 2001 were July, August, and September. May, June, July, September, and October met requirements in 2002. Annual diet overlap for each shark species-life stage combination was obtained by averaging monthly estimates for 2001 and 2002. Overall diet overlap (2001 and 2002 diet data combined) for each shark species-life stage combination was obtained by averaging monthly diet estimates across years. For comparison, and ignoring prey availability issues, estimates of diet overlap for each shark species-life stage combination were also calculated using all diet data combined (1999 to 2002).

In addition to using the arbitrary cutoff of 0.6, observed overlap values were compared to a distribution of expected overlap values based on a null model. The distribution of null model data came from 1000 randomizations of the 2001 and 2002 combined diet data (R3 randomization algorithm; Winemiller \& Pianka 1990). Simulations were performed using EcoSim v 7.41 software $^{2}$. The observed value was considered statisti-

${ }^{1}$ Krebs CJ (1999) Ecological methodology. Version 5.1. Department of Zoology, University of British Columbia. Available at: http:// nhsbig.inhs.uiuc.edu/wes/krebs.html

${ }^{2}$ Gotelli NJ, Entsminger GL (2003) EcoSim: null models software for ecology. Version 7. Acquired Intelligence \& Kesey-Bear, Burlington, VT. Available at: http://homepages.together.net/ gentsmin/ecosim.htm cally different from the null distribution if it was greater than or less than the simulated indices $95 \%$ of the time $(\mathrm{p}<0.05)$ (Winemiller \& Pianka 1990). An observed value less than the simulation index would suggest interspecific competition and diet partitioning among shark species-life stage combinations. A value greater than the simulation index would suggest a lack of competition among shark species-life stage combinations or strong competition that has not yet led to resource partitioning.

Habitat overlap. Gillnet data from fisheryindependent surveys off St. Vincent Island, Florida, from April through October 1996 to 2002 were used to assess habitat overlap of species-life stage combinations in the Apalachicola Bay system (J. K. Carlson, NMFS PC Laboratory, unpubl. data). The survey design is described in Carlson \& Brusher (1999). Weekly sets were made at depths of 3 to $10 \mathrm{~m}$ using the $186 \mathrm{~m}$ multipanel gillnet. In 2001 and 2002, the 100 m multi-panel gillnet was also used to supplement sample collection.

Habitat overlap was calculated on a daily basis using Schoener's overlap index where the resource state was gillnet set. Analysis was restricted to dates between May and October 1996 to 2002 when at least 2 gillnet sets (either the 186 or $100 \mathrm{~m}$ gillnet or both) were made and at least 2 of the 7 shark species-life stages were captured on the same day. The proportion, $p$, was calculated using the number of a particular shark species life stage captured at gillnet station $i$ divided by the total number of that particular species-life stage captured at all gillnet stations for that date. Seasonal habitat overlap was obtained for all species-life stage combinations by averaging daily estimates for a season for all years. Seasons were defined as: (1) spring (May), (2) summer (June, July, August), and (3) fall (September, October). Overall habitat overlap for all shark species-life stage combinations was obtained by averaging daily estimates across seasons and years.

Observed daily estimates of habitat overlap were compared to a distribution of expected overlap values based on a null model. Simulations were performed using EcoSim v 7.21 software $^{2}$. The observed overlap value was considered significantly different from the null distribution if the observed value was greater than or less than the simulated indices $95 \%$ of the time $(\mathrm{p}<0.05)$.

Prey size analysis. Prey size analysis was restricted to Atlantic sharpnose, blacktip, and finetooth sharks collected June through October of 2001 and 2002. All teleost prey types found whole in stomachs and reconstructed using regression equations were used in this analysis.

Size-selective feeding was examined by comparing sizes of potential fish prey from the field to sizes of prey that were recovered from stomachs. Because of low occurrence of measurable prey in the stomachs, 
length-frequency histograms were constructed for only 3 of the 5 major prey items taken from shark stomachs. Size-selective feeding on Brevoortia spp. was assessed for Atlantic sharpnose, blacktip, and finetooth sharks. Size-selective feeding on Micropognias undulatus and Stellifer lanceolatus was assessed for Atlantic sharpnose and blacktip sharks. Prey length frequencies were not distributed normally and a median test was applied to compare the 2 prey length groups (Zar 1999, p. 223-226).

To estimate changes in prey size with increasing shark size, absolute prey size-predator size diagrams were plotted for each shark. To determine if increases in the mean prey size (as determined by the 50th quantile) resulted from an increase in the maximum or minimum (or both) prey size taken, quantile regression techniques (Scharf et al. 2000) were used to determine the upper and lower bounds (90th and 10th quantiles) of the relation between prey size and shark size.

To examine the patterns of prey size use among sharks, relative and cumulative frequency histograms of prey size-predator size ratios and scatter diagrams of prey size-predator size ratios versus predator size were created for each shark. Regression quantiles (90th and 10th) were generated to estimate the edges of the ratio scatter diagrams for each shark species. Here, trophic niche breadth was examined by determining the changes in the range of relative prey sizes with increase in predator size. This was assessed by visually examining whether the 90th and 10th quantiles were parallel, converged, or diverged.

\section{RESULTS}

\section{Feeding habits}

\section{Atlantic sharpnose shark}

A total of 300 Atlantic sharpnose sharks were examined for dietary analysis from collections made April through October 1999 to 2002. Of these, 201 were young-of-the-year, 25 were juvenile, and 74 were adult.

Of the 201 young-of-the-year Atlantic sharpnose shark stomachs examined, 127 contained prey items and $74(36.82 \%)$ were empty. Items found in stomachs included teleosts (6 species representing 5 families), molluscs (cephalopod squid and 1 species of gastropod), arthropods (decapod crustaceans), angiosperms (Halodule beaudettei), and unidentifiable algae (Table 1). Crustaceans (mostly shrimp) dominated young-of-the-year diets $\left(81.60 \% \mathrm{IRI}_{\mathrm{PC}}\right)$. Sciaenids (mostly Micropogonias undulatus) were the second most important prey item (15.64\% IRI $\left._{\mathrm{PC}}\right)$. Prey items of little importance included clupeids and other pelagic teleosts $\left(\sim 2 \% \mathrm{IRI}_{\mathrm{PC}}\right.$ collectively), invertebrates other than crustaceans (mostly loliginid squid; $\sim 1 \% \mathrm{IRI}_{\mathrm{PC}}$ ), and epibenthic teleosts other than sciaenids (less than $0.1 \% \mathrm{IRI}_{\mathrm{PC}}$ collectively).

Out of 25 juvenile Atlantic sharpnose shark stomachs, 15 contained prey and $10(40 \%)$ were empty. Items found in stomachs included teleosts (6 species representing 6 families), molluscs (cephalopod squid), arthropods (shrimp and crab), angiosperms (Halodule beaudettei), and unidentifiable shell fragments (Table 1). Sciaenids (mostly Cynoscion spp.) dominated juvenile diets $\left(64.45 \% \mathrm{IRI}_{\mathrm{PC}}\right)$. Other important prey items included crustaceans (mostly shrimp; $17.57 \% \mathrm{IRI}_{\mathrm{PC}}$ ) and epibenthic teleosts other than sciaenids (mostly Bagre marinus; $10.83 \% \mathrm{IRI}_{\mathrm{PC}}$ ). Clupeids (mostly Brevoortia spp.; $\left.3.42 \% \mathrm{IRI}_{\mathrm{PC}}\right)$ and other pelagic teleosts $\left(2.79 \% \mathrm{IRI}_{\mathrm{PC}}\right)$ made up a small portion of juvenile diets. Invertebrates other than crustaceans were of little dietary importance (less than $1 \% \mathrm{IRI}_{\mathrm{PC}}$ collectively).

Empty adult Atlantic sharpnose shark stomachs numbered $31(42 \%)$ out of 74 . Items found in stomachs included teleosts ( 7 species representing 6 families), molluscs (cephalopod squid), arthropods (2 species representing 3 orders), angiosperms (Thalassia testudinum), and unidentifiable shell fragments (Table 1). Clupeids (mostly Brevoortia spp.) dominated adult diets $\left(58.15 \% \mathrm{IRI}_{\mathrm{PC}}\right)$. Other important prey items included crustaceans (mostly shrimp; $25.62 \% \mathrm{IRI}_{\mathrm{PC}}$ ) and sciaenids $\left(13.80 \% \mathrm{IRI}_{\mathrm{PC}}\right)$. Prey items of little importance included other pelagic and epibenthic teleosts $\left(\sim 1.2 \% \mathrm{IRI}_{\mathrm{PC}}\right.$ collectively) and other invertebrates ( 1\% 1 RI $\left.I_{\mathrm{PC}}\right)$.

\section{Blacktip shark}

A total of 230 blacktip sharks were examined for dietary analysis from collections made April through October 1999 to 2002. Of these, 75 were young-of-theyear and 155 were juvenile.

Young-of-the-year blacktip sharks had the lowest percentage of empty stomachs. Out of 75 examined, 57 contained prey items and 18 (24\%) were empty. Items found in stomachs included teleosts $(7$ species representing 6 families), arthropods (shrimp), and angiosperms (Thalassia testudinum) (Table 2). Sciaenids (mostly Micropogonias undulatus; $57.29 \% \mathrm{IRI}_{\mathrm{PC}}$ ) and clupeids (mostly Brevoortia spp.; $41.80 \% \mathrm{IRI}_{\mathrm{PC}}$ ) dominated young-of-the-year diets. Prey items of little importance included other pelagic or other epibenthic teleosts $\left(\sim 0.9 \%\right.$ IRI $_{\mathrm{PC}}$ collectively) and crustaceans (less than $0.1 \% \mathrm{IRI}_{\mathrm{PC}}$ ). Invertebrates other than crustaceans were absent from young-of-the-year blacktip stomachs.

Out of 155 juvenile blacktip shark stomachs that were examined, 66 (43\%) were empty. Items found in stomachs included teleosts (10 species representing 
10 families), molluscs (3 orders), arthropods (shrimp), and angiosperms (Halodule beaudettei) (Table 2). Clupeids dominated juvenile diets $\left(93.08 \%\right.$ IRI $\left._{\mathrm{PC}}\right)$. Sciaenids (mostly Micropogonias undulatus) were the second most important prey item (5.99\% $\left.\mathrm{IRI}_{\mathrm{PC}}\right)$. Pelagic

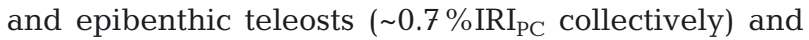
crustaceans and other invertebrates $\left(\sim 0.2 \%\right.$ IRI $_{\text {PC }}$ collectively) were of little dietary importance.

Table 1. Rhizoprionodon terraenovae. Diet composition of young-of-the-year $(235-330 \mathrm{~mm}$ fork length [FL]; mean $=278 \mathrm{~mm} ; \mathrm{N}=201,74$ empty), juvenile (490-700 mm FL; mean $=617 \mathrm{~mm} ; \mathrm{N}=25,10$ empty), and adult ( $670-865 \mathrm{~mm}$ FL; mean $=775 \mathrm{~mm} ; \mathrm{N}=74,31 \mathrm{empty})$ Atlantic sharpnose sharks by percent number $(\% \mathrm{~N})$, percent weight $(\% \mathrm{~W})$, percent frequency of occurrence $(\% \mathrm{O})$, index of relative importance on a percent basis (\%IRI), and index of relative importance on a percent basis for 6 major prey categories (\% IRI $I_{P C}$. Unid.: unidentifiable. No entries indicate prey item not present in diet

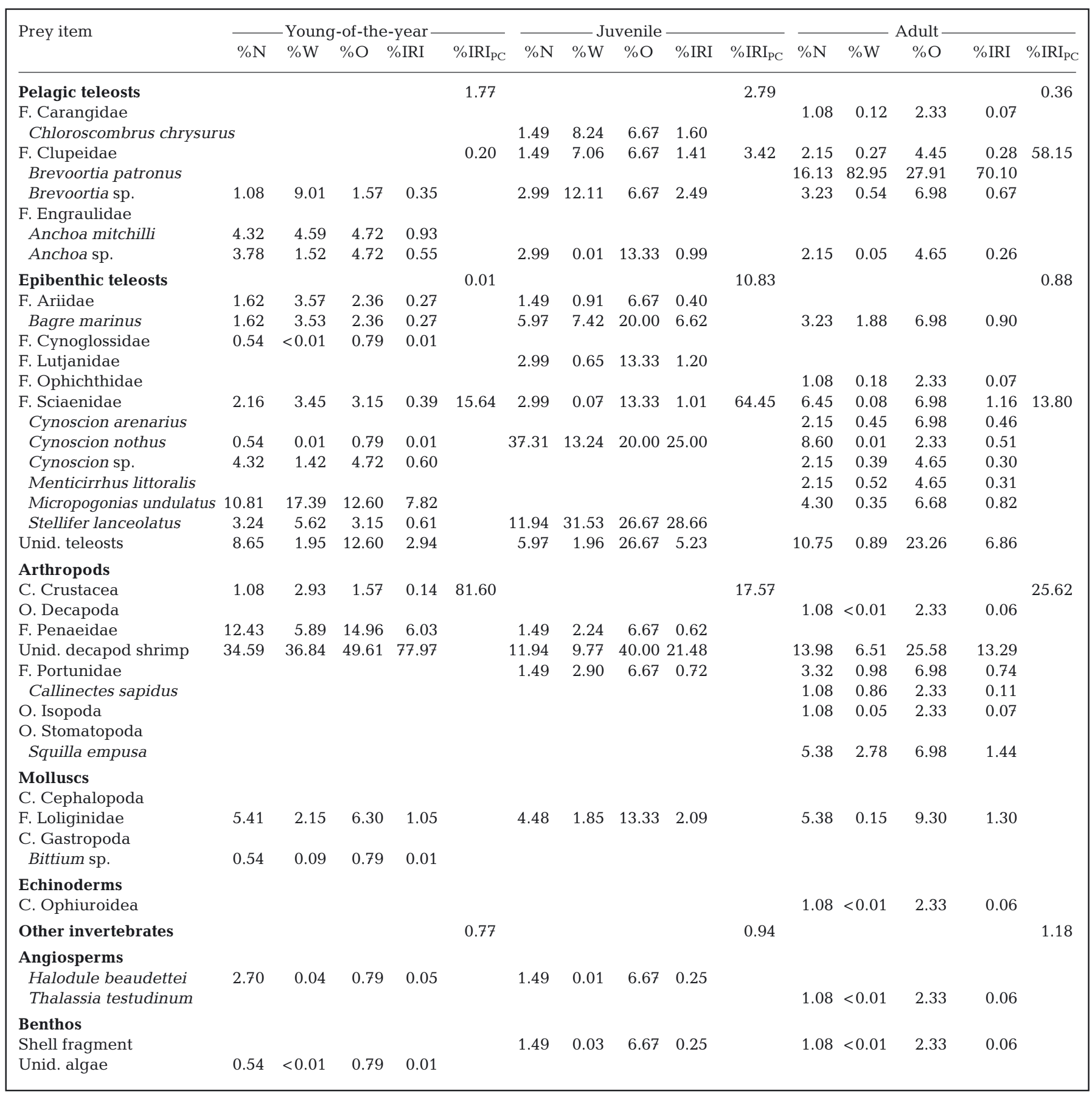


Table 2. Carcharhinus limbatus. Diet composition of young-of-the-year $(445-590 \mathrm{~mm}$ fork length [FL]; mean $=523 \mathrm{~mm} ; \mathrm{N}=75,18$ empty) and juvenile $(620-1030 \mathrm{~mm} \mathrm{FL}$; mean $=770 \mathrm{~mm} ; \mathrm{N}=155,66$ empty) blacktip sharks by percent number $(\% \mathrm{~N})$, percent weight $(\% \mathrm{~W})$, percent frequency of occurrence $(\% \mathrm{O})$, index of relative importance on a percent basis (\%IRI), and index of relative importance on a percent basis for 6 major prey categories (\% IRI $I_{P C}$ ). Unid.: unidentifiable. No entries indicate prey not present in diet

\begin{tabular}{|c|c|c|c|c|c|c|c|c|c|c|}
\hline \multirow[t]{2}{*}{ Prey item } & \multicolumn{5}{|c|}{-Young-of-the-year- } & \multicolumn{5}{|c|}{-Juvenile } \\
\hline & $\% \mathrm{~N}$ & $\% \mathrm{~W}$ & $\% \mathrm{O}$ & $\%$ IRI & $\% \mathrm{IRI}_{\mathrm{PC}}$ & $\% \mathrm{~N}$ & $\% W$ & $\% \mathrm{O}$ & $\%$ IRI & $\% \mathrm{IRI}_{\mathrm{PC}}$ \\
\hline Pelagic teleosts & & & & & 0.70 & & & & & 0.22 \\
\hline F. Carangidae & 1.32 & 0.04 & 1.75 & 0.07 & & 0.63 & 0.05 & 1.12 & 0.02 & \\
\hline F. Clupeidae & 6.58 & 7.27 & 8.77 & 3.52 & 41.80 & 15.00 & 3.28 & 21.35 & 9.05 & 93.08 \\
\hline Brevoortia patronus & 14.47 & 33. 19 & 14.04 & 19.40 & & 25.63 & 67.53 & 32.58 & 70.36 & \\
\hline Brevoortia sp. & 7.89 & 7.63 & 10.53 & 4.74 & & 10.00 & 8.93 & 13.48 & 5.92 & \\
\hline F. Elopidae & 1.32 & 0.87 & 1.75 & 0.11 & & & & & & \\
\hline Elops saurus & 1.32 & 3.09 & 1.75 & 0.22 & & 0.63 & 0.18 & 1.12 & 0.02 & \\
\hline \multicolumn{11}{|l|}{ F. Engraulidae } \\
\hline Anchoa sp. & & & & & & 1.88 & 0.02 & 3.37 & 0.15 & \\
\hline Epibenthic teleosts & & & & & 0.17 & & & & & 0.49 \\
\hline \multicolumn{11}{|l|}{ F. Ariidae } \\
\hline Bagre marinus & 1.32 & $<0.01$ & 1.75 & 0.07 & & 0.63 & $<0.01$ & 1.12 & 0.02 & \\
\hline F. Lutjanidae & & & & & & 0.63 & $<0.01$ & 1.12 & 0.02 & \\
\hline F. Sciaenidae & 1.32 & 0.05 & 1.75 & 0.07 & 57.29 & 0.63 & 0.02 & 1.12 & 0.02 & 5.99 \\
\hline Cynoscion arenarius & & & & & & 1.88 & 4.10 & 3.37 & 0.47 & \\
\hline Cynoscion sp. & 2.63 & 3.59 & 3.51 & 0.63 & & & & & & \\
\hline Leiostomus xanthurus & & & & & & 0.63 & 3.93 & 1.12 & 0.12 & \\
\hline Menticirrhus littoralis & 1.32 & 0.14 & 1.75 & 0.07 & & & & & & \\
\hline Micropogonias undulatus & 25.00 & 33.17 & 28.07 & 47.36 & & 5.63 & 6.49 & 8.99 & 2.52 & \\
\hline Stellifer lanceolatus & 9.21 & 5.27 & 7.02 & 2.95 & & 11.25 & 0.06 & 1.12 & 0.29 & \\
\hline \multicolumn{11}{|l|}{ F. Sparidae } \\
\hline Archosargus probatocephalus & & & & & & 0.63 & 2.69 & 1.12 & 0.09 & \\
\hline F. Syngnathidae & 1.32 & $<0.01$ & 1.75 & 0.07 & & 0.63 & 0.03 & 1.12 & 0.02 & \\
\hline Syngnathus sp. & & & & & & 0.63 & 0.14 & 1.12 & 0.02 & \\
\hline F. Synodontidae & & & & & & 0.63 & $<0.01$ & 1.12 & 0.02 & \\
\hline Unid. teleosts & 21.05 & 5.63 & 26.32 & 20.37 & & 18.30 & 0.52 & 25.72 & 10.69 & \\
\hline \multicolumn{11}{|l|}{ Arthropods } \\
\hline C. Crustecea & & & & & 0.04 & & & & & 0.14 \\
\hline \multicolumn{11}{|l|}{ O. Decapoda } \\
\hline \multicolumn{11}{|l|}{ F. Penaeidae } \\
\hline Litopenaeus satiferus & & & & & & 0.63 & 1.23 & 1.12 & 0.05 & \\
\hline Unid. decapod shrimp & 1.32 & 0.03 & 1.75 & 0.07 & & 1.25 & 0.76 & 2.25 & 0.10 & \\
\hline \multicolumn{11}{|l|}{ Molluscs } \\
\hline \multicolumn{11}{|l|}{ C. Cephalopoda } \\
\hline F. Loliginidae & & & & & & 0.63 & $<0.01$ & 1.12 & 0.02 & \\
\hline C. Gastropoda & & & & & & 0.63 & $<0.01$ & 1.12 & 0.02 & \\
\hline C. Isopoda & & & & & & 0.63 & 0.01 & 1.12 & 0.02 & \\
\hline \multicolumn{11}{|l|}{ Echinoderms } \\
\hline Other invertebrates & & & & & 0.00 & & & & & 0.08 \\
\hline \multicolumn{11}{|l|}{ Angiosperms } \\
\hline Halodule beaudettei & & & & & & 0.63 & $<0.01$ & 1.12 & 0.02 & \\
\hline Thalassia testudinum & 2.63 & 0.02 & 3.51 & 0.27 & & & & & & \\
\hline Benthos & & & & & & & & & & \\
\hline
\end{tabular}

\section{Finetooth shark}

A total of 109 juvenile finetooth sharks were examined for dietary analysis from collections made April through October 1999 to 2002. Of these, 14 were young-of-the-year and 95 were juveniles.

Half of the juvenile finetooth shark stomachs examined were empty; 55 contained prey items and 54
(49\%) were empty. Items found in stomachs included teleosts ( 5 species representing 6 families) and arthropods (shrimp; Table 3). Clupeids (mostly Brevoortia spp.) dominated finetooth diets $\left(97.29 \% \mathrm{IRI}_{\mathrm{PC}}\right)$. Other pelagic teleosts were the second most important prey item $\left(2.13 \% \mathrm{IRI}_{\mathrm{PC}}\right)$. Epibenthic teleosts other than sciaenids (less than 0.5\% $\mathrm{IRI}_{\mathrm{PC}}$ ) and crustaceans $\left(0.1 \%\right.$ IRI $\left._{\text {PC }}\right)$ were of little dietary importance. Sciaenids 
and invertebrates other than crustaceans were absent from finetooth stomachs.

\section{Spinner shark}

A total of 72 juvenile spinner sharks were examined for dietary analysis from collections made April through October 1999 to 2002. Of these, 48 were young-of-the-year and 24 were juvenile.

Half of the juvenile spinner shark stomachs examined were empty. Items found in stomachs included teleosts (3 species representing 4 families) and unidentifiable angiosperms (Table 4). Clupeids (mostly Brevoortia spp.) dominated spinner diets $\left(99.10 \% \mathrm{IRI}_{\mathrm{PC}}\right)$. Prey items of little importance included other pelagic and epibenthic teleosts (less than $1 \% \mathrm{IRI}_{\mathrm{PC}}$ collectively). Sciaenids, crustaceans, and other invertebrates were absent from spinner stomachs.

Table 3. Carcharhinus isodon. Diet composition of young-ofthe-year and juvenile combined (388-1070 mm fork length [FL]; mean $=778 \mathrm{~mm} ; \mathrm{N}=109,54$ empty) finetooth sharks by percent number $(\% \mathrm{~N})$, percent weight $(\% \mathrm{~W})$, percent frequency of occurrence $(\% \mathrm{O})$, index of relative importance on a percent basis (\%IRI), and index of relative importance for 6 major prey categories (\% IRI $\mathrm{IC}_{\mathrm{PC}}$ ). Unid.: unidentifiable. No entries indicate prey item not present in diet

\begin{tabular}{|c|c|c|c|c|c|}
\hline Prey item & $\% \mathrm{~N}$ & $\% \mathrm{~W}$ & $\% \mathrm{O}$ & $\%$ IRI & $\% \mathrm{IRI}_{\mathrm{PC}}$ \\
\hline Pelagic teleosts & & & & & 2.13 \\
\hline F. Carangidae & 3.95 & 0.21 & 5.45 & 0.43 & \\
\hline $\begin{array}{l}\text { Chloroscomborus } \\
\text { chrysurus }\end{array}$ & 1.32 & 0.26 & 1.82 & 0.05 & \\
\hline F. Clupeidae & 11.84 & 8.82 & 16.36 & 6.37 & 97.29 \\
\hline Brevoortia patronus & 38.16 & 74.66 & 36.36 & 77.31 & \\
\hline Brevoortia sp. & 15.79 & 9.84 & 18.18 & 8.78 & \\
\hline \multicolumn{6}{|l|}{ F. Elopidae } \\
\hline \multirow{2}{*}{\multicolumn{5}{|c|}{ F. Engraulidae }} & \\
\hline & & & & & \\
\hline Epibenthic teleosts & & & & & 0.49 \\
\hline F. Sciaenidae & & & & & 0.00 \\
\hline F. Sparidae & 1.32 & 0.60 & 1.82 & 0.07 & \\
\hline F. Syngnathidae & 2.63 & 0.28 & 3.64 & 0.20 & \\
\hline Syngnathus sp. & 1.32 & 1.32 & 1.82 & 0.09 & \\
\hline Unid. teleosts & 14.47 & 1.83 & 20.00 & 6.14 & \\
\hline \multicolumn{6}{|l|}{ Arthropods } \\
\hline $\begin{array}{l}\text { C. Crustacea } \\
\text { O. Decapoda }\end{array}$ & & & & & 0.10 \\
\hline Unid. decapod shrimp & 2.63 & 0.26 & 3.64 & 0.20 & \\
\hline \multicolumn{6}{|l|}{ Molluscs } \\
\hline \multicolumn{6}{|l|}{ Echinoderms } \\
\hline Other invertebrates & & & & & 0.00 \\
\hline \multicolumn{6}{|l|}{ Angiosperms } \\
\hline Benthos & & & & & \\
\hline
\end{tabular}

Table 4. Carcharhinus brevipinna. Diet composition of youngof-the-year and juvenile combined (460-960 mm fork length [FL]; mean $=639 \mathrm{~mm} ; \mathrm{N}=72,36$ empty) spinner sharks by percent number $(\% \mathrm{~N})$, percent weight $(\% \mathrm{~W})$, percent frequency of occurrence $(\% \mathrm{O})$, index of relative importance on a percent basis (\%IRI), and index of relative importance on a percent basis for 6 major prey categories (\%IRI $\mathrm{PC}_{\mathrm{PC}}$ ). Unid.: unidentifiable. No entries indicate prey item not present in diet

\begin{tabular}{|lccccc|}
\hline Prey item & $\% \mathrm{~N}$ & $\% \mathrm{~W}$ & $\% \mathrm{O}$ & $\% \mathrm{IRI}$ & $\% \mathrm{IRI}_{\mathrm{PC}}$ \\
\hline Pelagic teleosts & & & & & 0.54 \\
F. Clupeidae & 20.00 & 16.83 & 16.67 & 16.25 & 99.10 \\
$\quad$ Brevoortia patronus & 17.78 & 67.05 & 13.89 & 31.18 & \\
$\quad$ Brevoortia sp. & 13.33 & 5.99 & 11.11 & 5.68 & \\
F. Engraulidae & 2.22 & 0.01 & 2.78 & 0.16 & \\
$\quad$ Anchoa sp. & 4.44 & 0.20 & 2.78 & 0.34 & \\
Epibenthic teleosts & & & & & 0.36 \\
F. Ariidae & 2.22 & 0.03 & 2.78 & 0.17 & \\
F. Sciaenidae & & & & & 0.00 \\
F. Syngnathidae & 2.22 & 0.06 & 2.78 & 0.17 & \\
Unid. teleosts & 33.33 & 8.00 & 41.67 & 45.59 & \\
Arthopods & & & & & \\
C. Crustacea & & & & & 0.00 \\
Molluscs & & & & & \\
Echinoderms & & & & & \\
Other invertebrates & & & & & 0.00 \\
Angiosperms & & & & & \\
Unid. angiosperms & 2.22 & $<0.01$ & 2.78 & 0.16 & \\
Benthos & & & & & \\
\hline
\end{tabular}

Cumulative prey curves

In general, all species-life stage cumulative prey curves showed either well-defined asymptotes or trends toward an asymptote (Fig. 2). This indicates that sufficient stomachs were examined to describe diets for most of the species-life stages. The cumulative prey curves for juvenile Atlantic sharpnose, blacktip, and finetooth sharks show only a trend towards an asymptote (Fig. 1b,e,f); more juvenile Atlantic sharpnose, blacktip, and finetooth shark stomachs may need to be examined to fully describe the diets of these specieslife stages.

\section{Net-feeding}

There was little evidence of net-feeding (Table 5). Sciaenids were found more frequently fresh than digested in 4 out of 5 species-life stages of Atlantic sharpnose and blacktip sharks (Table 5a,b). Adult Atlantic sharpnose sharks showed some evidence of net-feeding on clupeids (Table 5a). No other specieslife stage showed a major difference between fresh and digested prey categories. 
Atlantic sharpnose shark
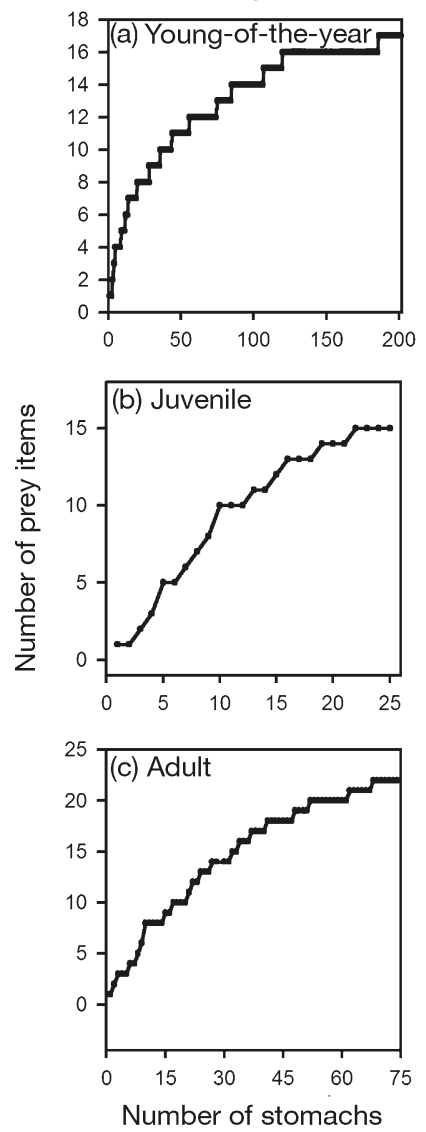

\section{Diet overlap}

Out of a total of 21 potential species-life stage combinations, mean annual diet overlap estimates were made for 9 combinations in 2001 and 15 combinations in 2002 (Table 6a,b). Mean annual diet overlap estimates were made for 19 species-life stage combinations from diet overlap estimates determined when months were combined over both years (Table 6c). Similar diet overlap results were obtained using all diet data combined (1999 to 2002; Table 6d). Using diet overlap data collected at the monthly level, there was significantly higher diet overlap for species-life stage combinations that were within $100 \mathrm{~mm}$ average FL of each other than species life stages that were greater or less than $100 \mathrm{~mm}$ average FL of each other (MannWhitney; $U=94.5, \mathrm{p}=0.0227$ ).

To avoid redundancy, null-model diet overlap results will be presented starting with young-of-the-year Atlantic sharpnose sharks and moving from left to right in the overlap matrix. For example, simulations between young-of-the-year Atlantic sharpnose sharks and all other species-life stages will be presented in the young-of-the-year Atlantic sharpnose shark para-

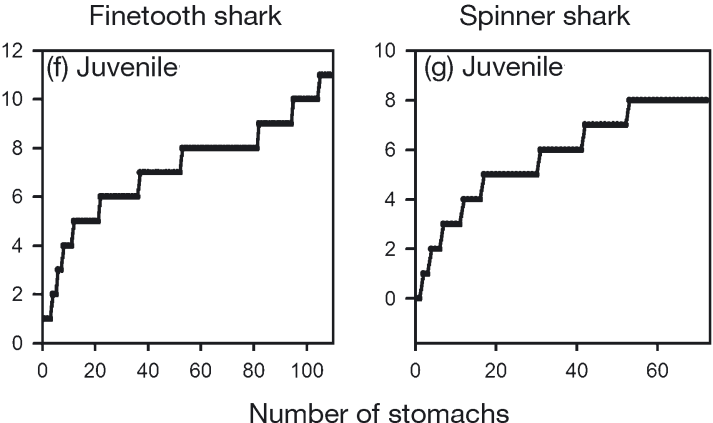

Fig. 2. Rhizoprionodon terraenovae, Carcharhinus limbatus, C. isodon, and C. brevipinna. Randomized cumulative prey curves of: (a) young-of-the-year ( $\mathrm{N}=201)$, (b) juvenile ( $\mathrm{N}=$ 25), and (c) adult $(\mathrm{N}=74)$ Atlantic sharpnose sharks; (d) young-of-the-year $(\mathrm{N}=75)$ and $(\mathrm{e})$ juvenile $(\mathrm{n}=155)$ blacktip sharks; (f) young-of-the-year and juvenile (combined; $\mathrm{N}=$ 109) finetooth sharks; and ( $\mathrm{g}$ ) young-of-the-year and juvenile (combined; $\mathrm{N}=72$ ) spinner sharks. Means are plotted

graph. Individual numbers within parentheses represent the number of times an observed overlap value was compared to the null model for a particular combination.

For all comparisons, young-of-the-year Atlantic sharpnose sharks showed very low diet overlap (Schoener's overlap index $<0.6$; Table 6). Null-model simulations were performed for young-of-the-year Atlantic sharpnose sharks versus all other species-life stages. Out of 9 null-model simulations performed, 7 were lower than expected. Of those 7 , one was significantly lower (vs young-of-the-year blacktip sharks; $\mathrm{p}=0.046$ ) and the other was not statistically different than expected.

Juvenile Atlantic sharpnose sharks showed low diet overlap $(<0.6)$ for all comparisons except versus juvenile blacktip sharks when all years were combined to calculate diet overlap (Table 6d). Nullmodel simulations were performed for juvenile Atlantic sharpnose sharks versus adult Atlantic sharpnose sharks (1 simulation), young-of-the-year (1) and juvenile blacktip sharks (1), and juvenile finetooth sharks. Two out of 4 values from null-model simulations were lower than expected. None of the observed diet overlap values were significantly higher or lower than random.

Adult Atlantic sharpnose sharks showed very high diet overlap with young-of-the-year blacktip sharks and borderline diet overlap with other Carcharhinus spp. life stages (Table 6b,c). All 10 observed diet overlap values for adult Atlantic sharpnose sharks versus young-of-the-year (3) and juvenile blacktip sharks (3), juvenile finetooth sharks (3), and juvenile spinner sharks (1) were higher than the null-model. Three 
Table 5. Rhizoprionodon terraenovae, Carcharhinus limbatus, C. isodon and C. brevipinna.Total number of identifiable prey (N) found either fresh or digested in shark stomachs and the percentage contribution of the 6 major prey categories to Fresh and Digested categories. Fresh prey $=$ no signs of digestion. Digested prey = partially digested (e.g. starting to lose scales or fins) to well digested (e.g. identifiable only by key morphological characteristics). YOY = young-of-the-year; JUV = juvenile; MAT = adult

\begin{tabular}{|c|c|c|c|c|c|c|}
\hline \multirow{2}{*}{ Prey item } & \multicolumn{2}{|c|}{ YOY } & \multicolumn{2}{|c|}{ JUV } & \multicolumn{2}{|c|}{ MAT } \\
\hline & Fresh & Digested & Fresh & Digested & Fresh & Digested \\
\hline \multicolumn{7}{|c|}{ (a) Atlantic sharpnose shark } \\
\hline $\mathrm{N}$ & 12 & 151 & 1 & 58 & 21 & 60 \\
\hline Family Clupeidae & 0.0 & 1.3 & 0.0 & 5.1 & 57.1 & 13.3 \\
\hline Other pelagic teleosts & 25.0 & 7.9 & 0.0 & 5.1 & 0.0 & 5.0 \\
\hline Family Sciaenidae & 58.4 & 21.9 & 100.0 & 55.9 & 4.8 & 38.3 \\
\hline Other epibenthic teleosts & 8.3 & 4.0 & 0.0 & 11.9 & 4.8 & 6.8 \\
\hline Crustaceans & 0.0 & 58.3 & 0.0 & 16.9 & 28.5 & 28.3 \\
\hline Other invertebrates & 8.3 & 6.6 & 0.0 & 5.1 & 4.8 & 8.3 \\
\hline \multicolumn{7}{|l|}{ (b) Blacktip shark } \\
\hline $\mathrm{N}$ & 3 & 55 & 15 & 116 & & \\
\hline Family Clupeidae & 33.3 & 83.6 & 66.8 & 84.5 & & \\
\hline Other pelagic teleosts & 0.0 & 5.5 & 0.0 & 4.3 & & \\
\hline Family Sciaenidae & 66.7 & 5.5 & 20.0 & 3.4 & & \\
\hline Other epibenthic teleosts & 0.0 & 3.6 & 6.7 & 4.3 & & \\
\hline Crustaceans & 0.0 & 1.8 & 6.7 & 2.6 & & \\
\hline Other invertebrates & 0.0 & 0.0 & 0.0 & 0.9 & & \\
\hline \multicolumn{7}{|l|}{ (c) Finetooth shark } \\
\hline $\mathrm{N}$ & & & 10 & 55 & & \\
\hline Family Clupeidae & & & 90.0 & 76.4 & & \\
\hline Other pelagic teleosts & & & 0.0 & 16.4 & & \\
\hline Family Sciaenidae & & & 0.0 & 0.0 & & \\
\hline Other epibenthic teleosts & & & 10.0 & 3.6 & & \\
\hline Crustaceans & & & 0.0 & 0.0 & & \\
\hline Other invertebrates & & & 0.0 & 3.6 & & \\
\hline \multicolumn{7}{|l|}{ (d) Spinner shark } \\
\hline $\mathrm{N}$ & & & 2 & 31 & & \\
\hline Family Clupeidae & & & 100.0 & 83.9 & & \\
\hline Other pelagic teleosts & & & 0.0 & 9.7 & & \\
\hline Family Sciaenidae & & & 0.0 & 0.0 & & \\
\hline Other epibenthic teleosts & & & 0.0 & 6.4 & & \\
\hline Crustaceans & & & 0.0 & 0.0 & & \\
\hline Other invertebrates & & & 0.0 & 0.0 & & \\
\hline
\end{tabular}

observed diet overlap values were significantly higher than expected: 1 versus young-of-the-year blacktip sharks $(p=0.026), 1$ versus juvenile blacktip sharks $(\mathrm{p}=0.014)$, and 1 versus juvenile finetooth sharks $(\mathrm{p}=$ $0.025)$. The remainder were not significantly different than random.

Young-of-the-year blacktip sharks had borderline to high diet overlap with other Carcharhinus spp. life stages (Table 6). Out of 14 null-model simulations performed for young-of-the-year blacktip sharks versus juvenile blacktip sharks (6), juvenile finetooth sharks (6), and juvenile spinner sharks (2), 12 observed values were higher than the null-model. Three observed diet overlap values were significantly higher: 2 versus juvenile blacktip sharks ( $\mathrm{p}=0.033$, $\mathrm{p}=0.029$ ) and 1 versus juvenile finetooth sharks ( $\mathrm{p}=$
0.034). The remainder were not significantly different than expected.

Juvenile blacktip, juvenile finetooth, and juvenile spinner sharks had very high diet overlap with each other (Table 6). All 8 observed diet overlap values for juvenile blacktip sharks versus juvenile finetooth sharks (6) and juvenile spinner sharks (2) were higher than expected. Two observed diet overlap values were significantly higher than expected: 1 versus juvenile finetooth sharks $(\mathrm{p}<0.001)$ and 1 versus juvenile spinner sharks $(p=0.043)$. The remainder were not significantly different than random. Both observed diet overlap values for juvenile finetooth sharks versus juvenile spinner sharks were higher than expected, and 1 was significantly higher than random $(p<0.001)$. The other was not significantly higher or lower than expected. 

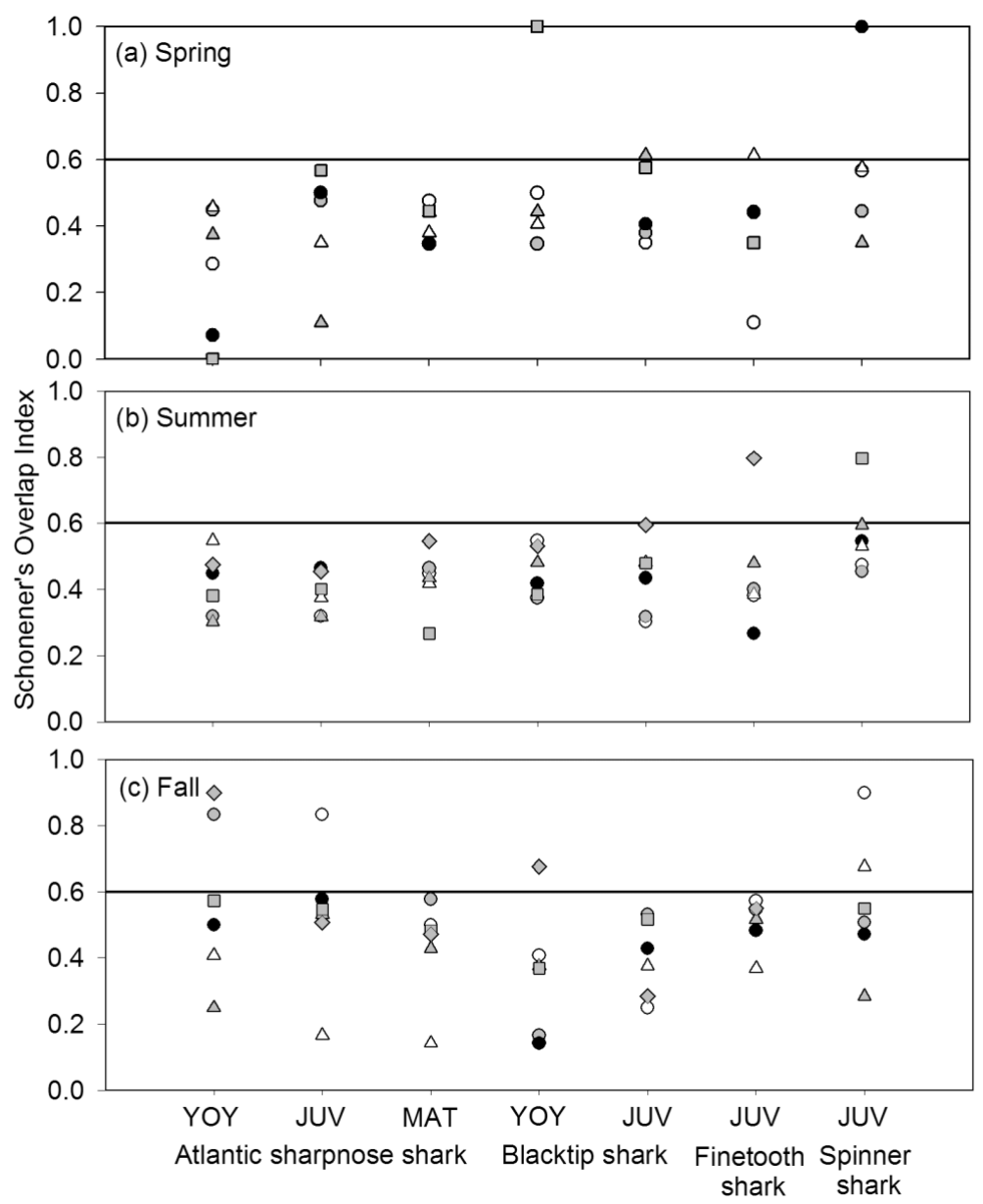

Fig. 3. Rhizoprionodon terraenovae, Carcharhinus limbatus, C. isodon, and $C$. brevipinna. Mean habitat overlap values for shark species-life stage combinations pooled across all years within (a) spring (May), (b) summer (June, July, August), (c) fall (September, October). Each symbol represents a mean overlap value for a particular species-life stage combination. Atlantic sharpnose sharks $=$ circles; blacktip sharks $=$ triangles; finetooth sharks = squares; spinner sharks = diamonds. YOY = young of the year, open symbols; JUV = juvenile, gray symbols; and MAT = adult, black symbols. Symbols $>0.6$ indicate 'biologically significant' overlap. Because of low sample sizes and relative consistency of diet with ontogeny, YOY and JUV life stages were combined for finetooth and spinner sharks

\section{Habitat overlap}

Mean seasonal habitat overlap between all specieslife stage combinations were calculated for 9 dates in the spring, 21 dates in the summer, and 10 dates in the fall (Fig. 3). The capture of different species-life stages in the same gillnet set on a given day was infrequent for nearly all combinations throughout all seasons in all years. Out of 40 dates that comparisons were made, high mean overlap (Schoener's overlap index equal to or greater than 0.6 ) occurred 6 times out of 63 combinations.
In the spring, 19 out of 21 mean habitat overlap values were biologically low $(<0.6)$. The 2 mean habitat overlap values that were higher than 0.6 in the spring were young-ofthe-year blacktip sharks versus juvenile spinner sharks and juvenile blacktip sharks versus juvenile finetooth sharks (1.00 and 0.612 respectively; Fig. 3a). Using spring data, a total of 17 independent null-model simulations were performed for young-of-theyear Atlantic sharpnose sharks, 15 for juvenile Atlantic sharpnose sharks, 20 for adult Atlantic sharpnose sharks, 7 for young-ofthe-year blacktip sharks, 9 for juvenile blacktip sharks, and 2 for juvenile finetooth sharks. Of 70 observed habitat overlap values in the spring, 69 were not significantly different than the expected mean. One simulation performed for young-of-the-year versus adult Atlantic sharpnose sharks was significantly higher than random ( $\mathrm{p}<0.01)$.

In the summer, 20 out of 21 mean habitat overlap values were biologically low $(<0.6)$. Juvenile finetooth sharks versus juvenile spinner sharks was the only combination that showed biologically high overlap (0.797; Fig. 3b). Using summer data, 51 independent null-model simulations were performed for young-of-the-year Atlantic sharpnose sharks, 35 for juvenile Atlantic sharpnose sharks, 54 for adult Atlantic sharpnose sharks, 39 for young-of-the-year blacktip sharks, 23 for juvenile blacktip sharks, and 8 for juvenile finetooth sharks. Of the 210 observed habitat overlap values in the summer, 202 were not significant from the nullmodel. Of the 8 that were significant, 5 were higher and 3 were lower (all $\mathrm{p}<0.001$ ).

In the fall, 18 out of 21 mean habitat overlap values were biologically low $(<0.6$; Fig. 3c). Juvenile spinner sharks showed biologically high mean habitat overlap with young-of-theyear blacktip sharks (0.676) and young-of-theyear Atlantic sharpnose sharks (0.900). Youngof-the-year Atlantic sharpnose sharks also showed high mean habitat overlap with juvenile Atlantic sharpnose sharks (0.834). Using fall data, 14 independent null-models were performed for young-of-theyear Atlantic sharpnose sharks, 14 for juvenile Atlantic sharpnose sharks, 9 for adult Atlantic sharpnose sharks, 15 for young-of-the-year blacktip sharks, 9 for juvenile blacktip sharks, and 6 for juvenile finetooth sharks. Of the 67 observed habitat overlap values in the fall, 61 were non-significant. Of the 6 that were significant, 3 were significantly higher and 3 were significantly lower (all $\mathrm{p}<0.007$ ). 
Table 6. Rhizoprionodon terraenovae, Carcharhinus limbatus, C. isodon and C. brevipinna. Mean ( \pm SE) symmetrical diet overlap matrices for shark species-life stage combinations calculated from (a) monthly estimates for 2001; (b) monthly estimates for 2002; (c) monthly estimates for 2001 and 2002 combined; and (d) combined diet data from 1999-2002. Entries in bold represent 'biologically significant' overlap. Blank entries indicate the combination did not meet analysis inclusion criteria. ATSH $=$ Atlantic sharpnose; BTIP = blacktip; FTTH = finetooth; SPIN = spinner. YOY = young-of-the-year; JUV = juvenile; MAT = adult

\begin{tabular}{|c|c|c|c|c|c|c|}
\hline & ATSH YOY & ATSH JUV & ATSH MAT & BTIP YOY & BTIP JUV & FTTH \\
\hline \multicolumn{7}{|l|}{ (a) 2001} \\
\hline ATSH JUV & & - & & & & \\
\hline ATSH MAT & & 0.486 & - & & & \\
\hline BTIP YOY & & 0.093 & 0.437 & - & & \\
\hline BTIP JUV & & 0.017 & 0.039 & $0.598(0.204)$ & - & \\
\hline FTTH & & & & & 0.921 & - \\
\hline SPIN & & & & 0.289 & 0.790 & \\
\hline \multicolumn{7}{|l|}{ (b) 2002} \\
\hline ATSH JUV & & - & & & & \\
\hline ATSH MAT & $0.160(0.080)$ & & - & & & \\
\hline BTIP YOY & $0.030(0.030)$ & & $0.821(0.122)$ & - & & \\
\hline BTIP JUV & $0.140(0.140)$ & & $0.578(0.015)$ & $0.614(0.020)$ & - & \\
\hline FTTH & $0.024(0.016)$ & & $0.726(0.218)$ & $0.679(0.087)$ & $0.832(0.099)$ & - \\
\hline SPIN & 0.000 & & 0.508 & 0.547 & 0.916 & 0.922 \\
\hline \multicolumn{7}{|l|}{ (C) 2001, 2002} \\
\hline ATSH JUV & & - & & & & \\
\hline ATSH MAT & $0.162(0.078)$ & 0.486 & - & & & \\
\hline BTIP YOY & $0.031(0.031)$ & 0.269 & $0.705(0.135)$ & - & & \\
\hline BTIP JUV & $0.145(0.145)$ & 0.045 & $0.567(0.102)$ & $0.513(0.118)$ & - & \\
\hline FTTH & $0.024(0.016)$ & 0 & $0.599(0.179)$ & $0.528(0.129)$ & $0.911(0.038)$ & - \\
\hline SPIN & 0.000 & & 0.508 & $0.418(0.129)$ & $0.864(0.074)$ & $0.891(0.101)$ \\
\hline \multicolumn{7}{|l|}{ (d) 1999-2002 } \\
\hline ATSH JUV & 0.355 & - & & & & \\
\hline ATSH MAT & 0.408 & 0.370 & - & & & \\
\hline BTIP YOY & 0.167 & 0.616 & 0.562 & - & & \\
\hline BTIP JUV & 0.066 & 0.103 & 0.651 & 0.482 & - & \\
\hline FTTH & 0.015 & 0.061 & 0.591 & 0.427 & 0.939 & - \\
\hline SPIN & 0.008 & 0.043 & 0.589 & 0.425 & 0.937 & 0.982 \\
\hline
\end{tabular}

\section{Prey size analysis}

Predictive equations

Over 2500 fish representing 30 species in 12 families ranging in size from 28 to $650 \mathrm{~mm}$ total length were collected as potential prey. Regressions relating external morphological measurements to total or fork length for 5 significant prey items were all highly significant ( $\mathrm{p}<0.0001)$, having $\mathrm{r}^{2}$ values ranging from 0.83 to 0.98 (Table 7). Regressions from measurements of total sagittal otolith weight were more variable than those using other measurements. The use of predictive equations increased the size information available for prey items by an order of magnitude.

\section{Prey size selectivity}

Length frequency distributions of Brevoortia spp., Micropogonias undulatus, and Stellifer lanceolatus found in Atlantic sharpnose, blacktip, and finetooth shark stomachs were compared separately to the frequency distributions of lengths collected by the NMFS sampling gear and by the NMFS and FMRI sampling gear combined. Atlantic sharpnose (Fig. 4a) and finetooth sharks (Fig. 4c) trended towards negative size-selectivity for Brevoortia spp. using the NMFS length data, but the comparisons were nonsignificant (Atlantic sharpnose sharks, $p=0.2250$; finetooth sharks, $\mathrm{p}=0.3821$ ); neutral size-selectivity for Brevoortia spp. was observed when all length data were combined (Atlantic sharpnose sharks, $\mathrm{p}=$ 0.9721; finetooth sharks, $\mathrm{p}=0.6759$ ). Blacktip sharks (Fig. 4b) showed neutral size-selectivity for Brevoortia spp. (NMFS data, $\mathrm{p}=0.8509$; NMFS/FMRI data, $\mathrm{p}=0.8462)$. The small Brevoortia spp. taken inside the bay by FMRI were rarely found in finetooth shark stomachs, and never found in Atlantic sharpnose or blacktip shark stomachs. Using the combined length data, size selectivity for $M$. undulatus by Atlantic sharpnose sharks was negative (Fig. $4 \mathrm{~d}_{i} \mathrm{p}<$ 0.0001); for blacktip, it was neutral (Fig. 4e; $\mathrm{p}=0.9675)$. M. undulatus data should be viewed 
with caution because predicted values of total length were obtained from extrapolating beyond the regression data range (Table 7). Atlantic sharpnose sharks showed marginally significant negative size selectivity for $S$. lanceolatus (Fig. 4f; $\mathrm{p}=0.0571$ ), but blacktip shark size-selection was positive (Fig. 4g; $\mathrm{p}<0.0001)$.

\section{Prey size-predator size relationships}

Absolute prey sizes increased significantly with increasing FL for Atlantic sharpnose and blacktip sharks (Fig. 5). As predator FL increased, both the maximum and minimum prey size consumed by Atlantic sharpnose increase significantly (Fig. 5a). For blacktip sharks, the maximum prey size consumed showed significant increase with increasing shark FL and the minimum prey size consumed showed only a marginal increase (Fig. 5b). The elation of prey size to finetooth shark FL was not significant for any regression. This was probably due to low sample size.

Atlantic sharpnose, blacktip, and finetooth sharks all consumed prey that were small fractions of their length (Fig. 6). Over $60 \%$ of the diets of Atlantic sharpnose and finetooth sharks consisted of prey that were less than $20 \%$ of their length (Fig. 6a,c). In con- trast, blacktip sharks incorporated relatively larger prey in its diet; $58 \%$ of blacktip shark diet consisted of prey that was more than $20 \%$ of its length (Fig. 6b). No shark diet consisted of relatively large prey; all prey were less than $36 \%$ of shark length. Relative prey size (prey size-predator size ratio plotted vs predator length) demonstrated a significant declining trend with increasing predator size for all 3 sharks (Fig. 7). Atlantic sharpnose sharks showed a decrease in the range of relative prey sizes taken with increasing body size (quantiles converged; Fig. 7a); however, blacktip sharks showed no change in range of relative prey sizes taken with increasing body size (quantiles parallel; Fig. 7b). This relationship was not examined for finetooth sharks due to low sample size (Fig. 7c).

\section{DISCUSSION}

This study represents the first attempt at quantifying the diets, diet overlap, and habitat overlap of early-life stages of several shark species. For finetooth and spinner sharks, this represents the first quantitative information on foraging ecology. Additionally, the sizestructured predator-prey data presented here are some of the first for these sharks and their teleost prey.

Table 7. Least squares regression equations relating prey length to prey measurements for 5 significant teleost prey items in the diets of the shark species-life stages. Prey items are listed in alphabetical order according to their family and scientific name. FL $=$ fork length $(\mathrm{mm}) ; \mathrm{TL}=$ total length $(\mathrm{mm})$. Prey measurements were: $\mathrm{BD}=$ body depth $(\mathrm{mm}), \mathrm{CPD}=$ caudal peduncle depth $(\mathrm{mm})$, $\mathrm{SOL}=$ snout to operculum length $(\mathrm{mm})$, and TOW $=$ total otolith weight $(\mathrm{g})$. Syx = standard error of regression coefficient; r-squared values $=$ coefficients of determination; $\mathrm{N}=$ number of fish measured. All regressions are highly significant $(\mathrm{p}<0.0001)$

\begin{tabular}{|c|c|c|c|c|c|}
\hline Prey species & Equation & Size range & Syx & r-squared & $\mathrm{N}$ \\
\hline \multicolumn{6}{|l|}{ F. Ariidae } \\
\hline \multirow{4}{*}{$\begin{array}{l}\text { Bagre marinus } \\
\text { (gaftopsail catfish) }\end{array}$} & $\mathrm{FL}=4.8690(\mathrm{BD})+26.5415$ & $55-600 \mathrm{~mm}$ FL & 0.0182 & 0.9528 & 144 \\
\hline & $\mathrm{FL}=14.9927(\mathrm{CPD})-16.7754$ & & 0.0181 & 0.9613 & 120 \\
\hline & $\mathrm{FL}=3.7724(\mathrm{SOL})+33.9460$ & & 0.0098 & 0.9866 & 142 \\
\hline & $\mathrm{FL}=68.3877(\mathrm{TOW})+171.9117$ & & 0.0303 & 0.8779 & 135 \\
\hline \multicolumn{6}{|l|}{ F. Clupeidae } \\
\hline \multirow{3}{*}{$\begin{array}{l}\text { Brevoortia spp. } \\
\text { (menhaden) }\end{array}$} & $\mathrm{FL}=2.7060(\mathrm{BD})+20.3968$ & 115-295 mm FL & 0.0171 & 0.9587 & 144 \\
\hline & $\mathrm{FL}=10.0422(\mathrm{CPD})+15.4794$ & & 0.0203 & 0.8968 & 252 \\
\hline & $\mathrm{FL}=3.9450(\mathrm{SOL})-23.9203$ & & 0.0196 & 0.9444 & 146 \\
\hline \multicolumn{6}{|l|}{ F. Sciaenidae } \\
\hline \multirow{4}{*}{$\begin{array}{l}\text { Cynoscion arenarius } \\
\text { (sand seatrout) }\end{array}$} & $\mathrm{TL}=5.5546(\mathrm{BD})-17.2871$ & $65-340 \mathrm{~mm} \mathrm{TL}$ & 0.0279 & 0.9704 & 40 \\
\hline & $\mathrm{TL}=14.6235(\mathrm{CPD})-19.1422$ & & 0.0360 & 0.9507 & 40 \\
\hline & $\mathrm{TL}=3.6508(\mathrm{SOL})+30.9773$ & & 0.0347 & 0.9543 & 40 \\
\hline & $\mathrm{TL}=343.1364(\mathrm{TOW})+94.1085$ & & 0.0666 & 0.8444 & 37 \\
\hline \multirow{4}{*}{$\begin{array}{l}\text { Micropogonias undulatus } \\
\text { (Atlantic croaker) }\end{array}$} & $\mathrm{TL}=3.1539(\mathrm{BD})+36.9735$ & $125-185 \mathrm{~mm} \mathrm{TL}$ & 0.0450 & 0.9210 & 41 \\
\hline & $\mathrm{TL}=12.7963(\mathrm{CPD})+3.8134$ & & 0.0680 & 0.8332 & 38 \\
\hline & $\mathrm{TL}=3.1497(\mathrm{SOL})+46.5881$ & & 0.0468 & 0.9055 & 42 \\
\hline & $\mathrm{TL}=260.7964(\mathrm{TOW})+104.8578$ & & 0.0520 & 0.8920 & 42 \\
\hline \multirow{4}{*}{$\begin{array}{l}\text { Stellifer lanceolatus } \\
\text { (star drum) }\end{array}$} & $\mathrm{TL}=3.5547(\mathrm{BD})+9.5699$ & $28-175 \mathrm{~mm} \mathrm{TL}$ & 0.0362 & 0.9463 & 43 \\
\hline & $\mathrm{TL}=11.9011(\mathrm{CPD})-2.6273$ & & 0.0518 & 0.9249 & 30 \\
\hline & $\mathrm{TL}=3.8262(\mathrm{SOL})+23.9079$ & & 0.0721 & 0.8491 & 31 \\
\hline & $\mathrm{TL}=748.9227(\mathrm{TOW})+54.7936$ & & 0.0541 & 0.8887 & 40 \\
\hline
\end{tabular}



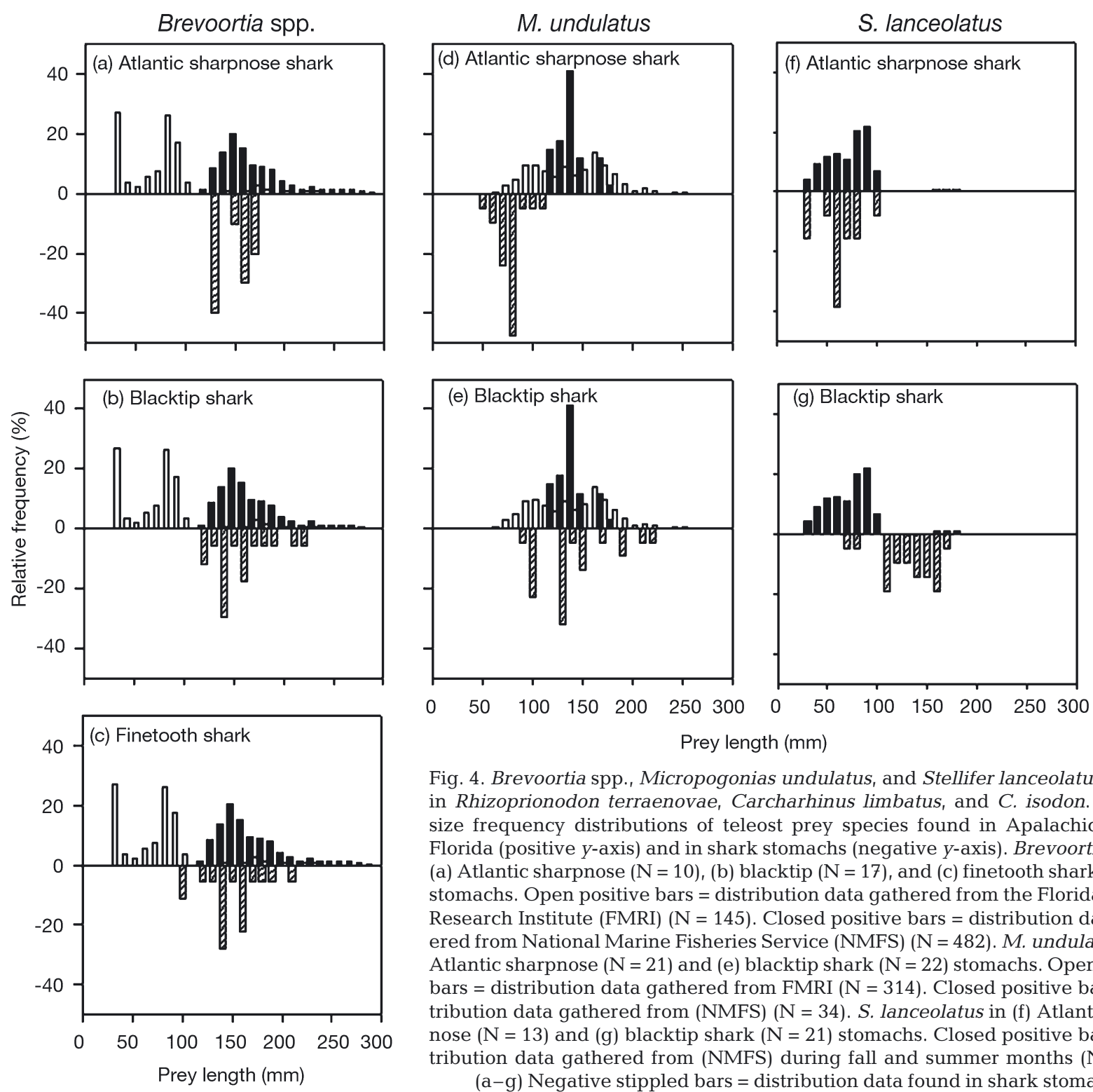

Prey length $(\mathrm{mm})$

Fig. 4. Brevoortia spp., Micropogonias undulatus, and Stellifer lanceolatus as prey in Rhizoprionodon terraenovae, Carcharhinus limbatus, and C. isodon. Relative size frequency distributions of teleost prey species found in Apalachicola Bay, Florida (positive $y$-axis) and in shark stomachs (negative $y$-axis). Brevoortia spp. in (a) Atlantic sharpnose ( $\mathrm{N}=10)$, (b) blacktip $(\mathrm{N}=17)$, and (c) finetooth shark $(\mathrm{N}=17)$ stomachs. Open positive bars = distribution data gathered from the Florida Marine Research Institute (FMRI) $(\mathrm{N}=145)$. Closed positive bars = distribution data gathered from National Marine Fisheries Service (NMFS) $(\mathrm{N}=482)$. M. undulatus in (d) Atlantic sharpnose $(\mathrm{N}=21)$ and $(\mathrm{e})$ blacktip shark $(\mathrm{N}=22)$ stomachs. Open positive bars = distribution data gathered from FMRI $(\mathrm{N}=314)$. Closed positive bars = distribution data gathered from (NMFS) $(\mathrm{N}=34)$. S. lanceolatus in (f) Atlantic sharpnose $(\mathrm{N}=13)$ and $(\mathrm{g})$ blacktip shark $(\mathrm{N}=21)$ stomachs. Closed positive bars = distribution data gathered from (NMFS) during fall and summer months $(\mathrm{N}=119)$.

$(\mathrm{a}-\mathrm{g})$ Negative stippled bars $=$ distribution data found in shark stomachs

\section{Feeding habits}

Atlantic sharpnose sharks were largely piscivorous; however, prey types found in this study were somewhat different than teleost prey types found in other studies. For example, Barry (2002) examined 54 young-of-theyear and juvenile Atlantic sharpnose sharks from Terrebonne Bay, Louisiana, and found Brevoortia patronus to be the most important prey item (43.09\%IRI). Shrimp and squid were also important prey items (10.19\%IRI and $2.55 \%$ IRI, respectively), but sciaenids were absent from the diet. Gelsleichter et al. (1999) examined stomachs from 208 (mostly adult) Atlantic sharpnose from the Mid-Atlantic Bight and concluded that teleost prey made up a significant portion of the diet (mostly para- lichthyid flounder; $64 \%$ IRI), followed by crustaceans (mostly portunids; $34 \%$ IRI). These observed differences in diet may be due to methodology and/or prey availability by region. For example, Barry (2002) excluded stomachs that contained only otoliths (which were included in this study) while Gelsleichter et al. (1999) sampled sharks obtained from longlines only. In addition, flatfishes, which may be a more common prey item in the Mid-Atlantic bight, were absent from the diet of Atlantic sharpnose sharks and did not appear in any collection of prey sampling.

As with Atlantic sharpnose sharks, blacktip shark prey types and their importance differed by study. Heupel \& Hueter (2002) examined 693 juvenile blacktip shark stomachs from Terra Ceia Bay, Florida, and 


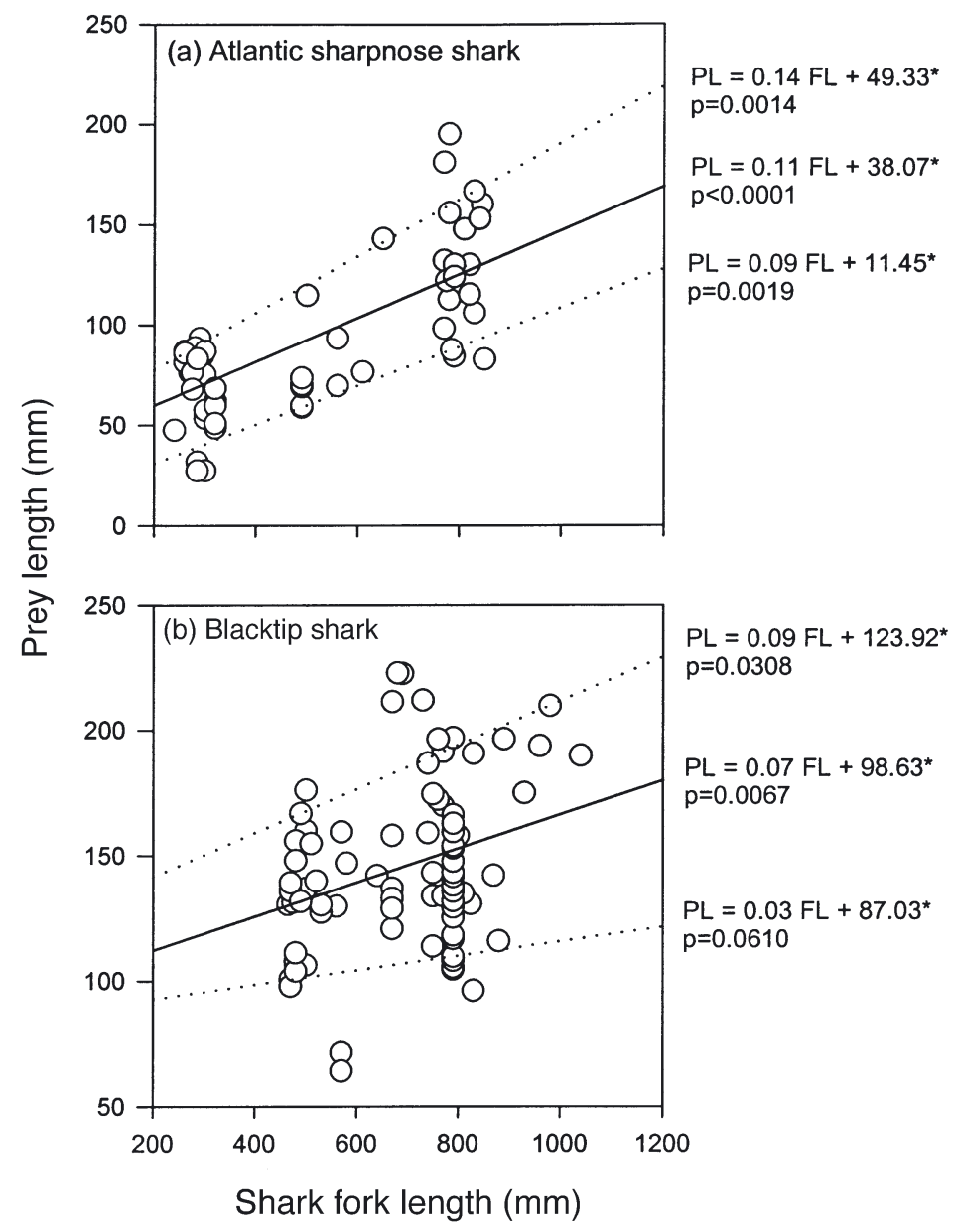

Fig. 5. Rhizoprionodon terraenovae and Carcharhinus limbatus. Prey size-predator size scatter diagrams for (a) Atlantic sharpnose $(\mathrm{N}=57)$ and (b) blacktip sharks $(\mathrm{N}=85)$. Lines represent quantile regressions used to examine changes in prey size eaten with increasing shark size. (-) Median prey sizes (50th quantile); $(\cdots)$ minimum and maximum prey sizes (10th and 90th quantiles); (O) single teleost prey eaten by a shark. $\mathrm{PL}=$ prey length $(\mathrm{mm}) ; \mathrm{FL}=$ shark fork length $(\mathrm{mm})$. ${ }^{*}$ Significance at $\mathrm{p}<0.05$

found sparids (mostly Lagodon rhomboides; $28.7 \%$ IRI), clupeids (mostly Opisthonema oglinum; $22.7 \%$ IRI), sciaenids (mostly Bairdiella chrysoura; $13.2 \%$ IRI), and haemulids (mostly Orthopristis chrysoptera; $13.8 \%$ IRI) as the most important teleosts in the diet. Barry (2002) examined 353 young-of-the-year and juvenile blacktip sharks from Terrebonne Bay, Louisiana, and reported Brevoortia patronus $(74.79 \%$ IRI) and sciaenids (mostly Micropogonias undulatus, $14.84 \%$ IRI) as the most common teleosts in the diet. The lack of sparids in blacktip shark stomachs in this study is likely attributed to regional diet differences. Again, differences in the importance of sciaenids in this study and Barry's (2002) study are more likely due to his elimination of otoliths from the dietary analysis.
Quantitative diet information for the finetooth and spinner shark has not been published. Castro (1993) published descriptive diet data for the finetooth shark in the northwest Atlantic off the coasts of South Carolina and Daytona Beach, Florida, and found teleosts (Brevoortia tyrannus, Leiostomus xanthurus, Scom-
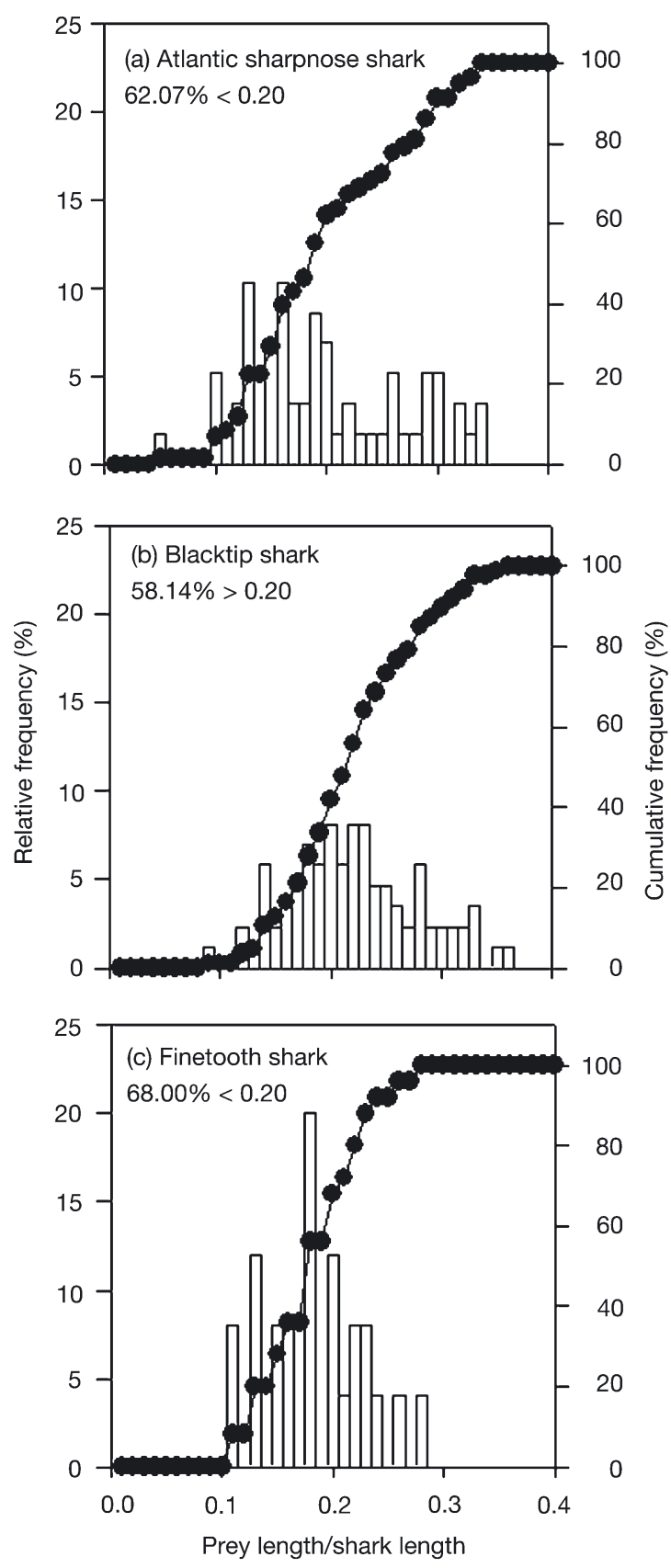

Fig. 6. Rhizoprionodon terraenovae, Carcharhinus limbatus, and $C$. isodon. Distributions of prey size-predator size ratios for (a) Atlantic sharpnose, (b) blacktip, and (c) finetooth sharks. Open bars $=$ relative frequencies at $0.1 \%$ intervals. Filled circles $=$ cumulative frequencies at $0.1 \%$ intervals 
beromorus maculatus, and Mugil sp.) to be the primary prey. Stevens \& McLoughlin (1991) published a diet description for the spinner shark from the southwest
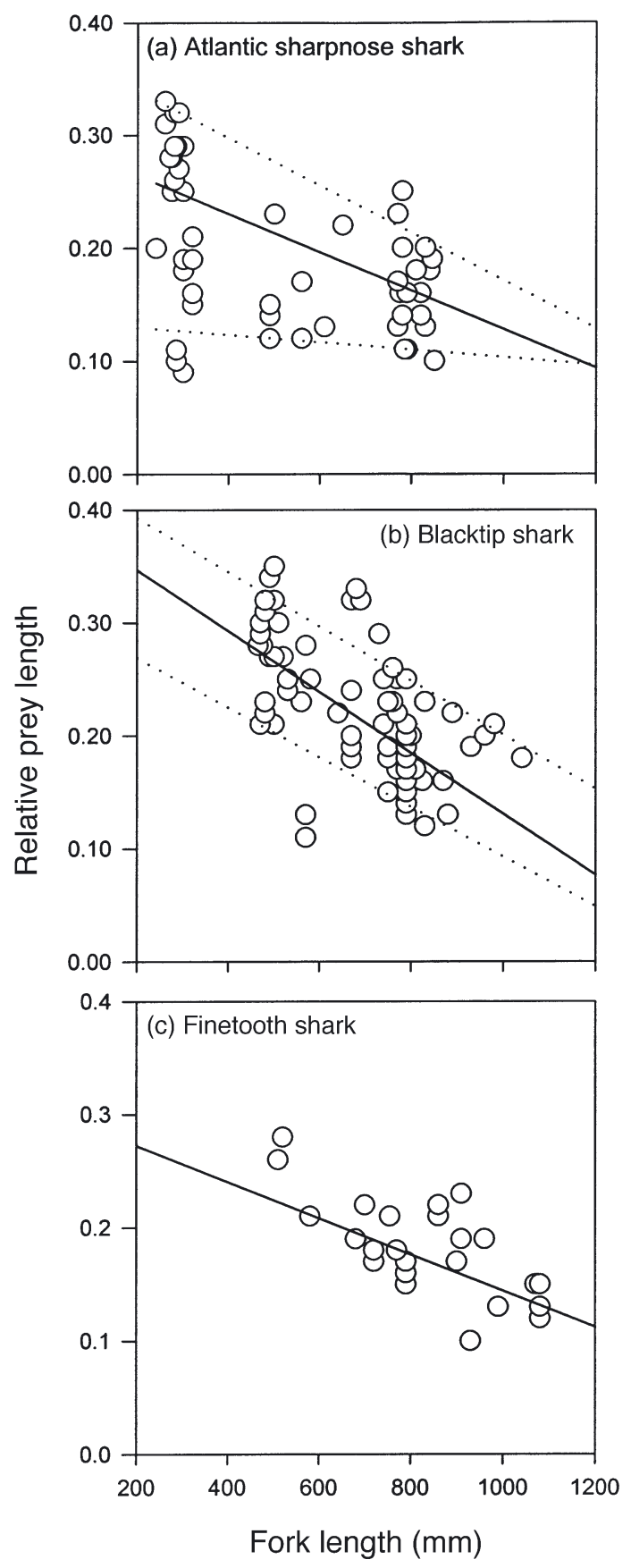

Fig. 7. Rhizoprionodon terraenovae, Carcharhinus limbatus, and $C$. isodon. Scatter diagrams show prey size-predator size ratio as a function of predator size for (a) Atlantic sharpnose, (b) blacktip, and (c) finetooth sharks. (O) Ratio of a single teleost prey eaten. Regression lines indicate change in the ranges of relative prey sizes eaten (trophic niche breadth) with increasing shark size. (-) Median ratios (50th quantile; $(\cdots)$ minimum and maximum ratios (10th and 90th quantiles)
Pacific Ocean and noted pelagic teleost fish to occur in the diets most often. In this study, juvenile finetooth and spinner sharks fed almost entirely on menhaden and showed no ontogenetic shift in diet.

Net-feeding most likely did not bias the diet indices. Sciaenids were found more frequently fresh than digested in the diets, but, in general, sciaenids were seldom collected in the gillnets (45 of 232 sciaenids collected from gillnet sets in 1999 to 2002). If any netfeeding occurred, the influence on the diet indices was likely minimal because it was infrequent (e.g. 64 fresh vs 526 digested prey items found in the stomachs). Moreover, teleost species commonly collected in large numbers as bycatch in the gillnets (e.g. gafftopsail catfish Bagre marinus, and Spanish mackerel Scomberomorus maculatus) were seldom, if ever, seen in the diets.

Unlike many teleosts that feed on plankton and invertebrates early in life and are exclusively piscivorous later in life (Popova 1978), Atlantic sharpnose, blacktip, finetooth, and spinner sharks found in Apalachicola Bay, Florida, are capable of feeding on fish from birth. However, ontogenetic shifts in prey type were observed for Atlantic sharpnose and blacktip sharks. Atlantic sharpnose sharks shifted from crustaceans and sciaenids (sharks 235 to $330 \mathrm{~mm}$ FL) to sciaenids and other epibenthic fish (sharks 499 to $700 \mathrm{~mm}$ FL), and then to Brevoortia spp., sciaenids, and crustaceans (sharks 670 to $865 \mathrm{~mm}$ FL). Blacktip sharks shifted from sciaenids and other epibenthic fish (sharks 445 to $590 \mathrm{~mm}$ FL) to almost exclusively Brevoortia species (sharks 620 to $1030 \mathrm{~mm}$ FL). Ontogenetic shifts in diet are not uncommon and have been observed in lemon sharks Negaprion brevirostris (Cortés \& Gruber 1990), tiger sharks Galeocerdo cuvier (Lowe et al. 1996), Galapagos sharks Carcharhinus galapagensis (Wetherbee et al. 1996), starspotteddogfish Mustelus manazo (Yamaguchi \& Taniuchi 2000), dusky sharks Carcharhinus obscurus (Simpfendorfer et al. 2001), and sevengill sharks Notorhynchus cepedianus (Ebert 2002). In this study, the diet shift may be attributed to larger Atlantic sharpnose and blacktip sharks being capable of capturing faster, pelagic prey. However, there appears to be an upper limit to the types and sizes of prey that these sharks can take; relatively large bluefish Pomatomus saltatrix, Spanish mackerel Scomberomorus maculatus, Florida pompano Trachinotus carolinus, and other elasmobranchs were collected in this system, but were never observed in the diets.

\section{Dietary overlap}

Shark size should be taken into account when developing hypotheses in elasmobranch resource partition- 
ing studies. Although diet overlap was low for most species-life stage comparisons, diet overlap was generally higher for species-life stages that were similar in size (within $100 \mathrm{~mm}$ FL of each other). Significant diet overlap was observed between juvenile blacktip, finetooth, and spinner sharks. Adult Atlantic sharpnose sharks showed borderline significant overlap with these species-life stages as well. On average, these 4 species-life stages are very close in size $(770,778$, 640, and $776 \mathrm{~mm} \mathrm{FL,} \mathrm{respectively).} \mathrm{Observed} \mathrm{diet}$ overlap was high between juvenile Atlantic sharpnose and young-of-the-year blacktip sharks when overlap was calculated using combined diet data (1999 to 2002). These 2 species-life stages are also close in average size (607 and $523 \mathrm{~mm} \mathrm{FL,} \mathrm{respectively).}$ Observed diet overlap was very low between youngof-the-year Atlantic sharpnose sharks and every other species-life stage. Young-of-the-year Atlantic sharpnose sharks are on average $300+\mathrm{mm}$ FL smaller than juvenile Atlantic sharpnose and young-of-the-year blacktip sharks and 500+ mm FL smaller than the other species-life stages. Diet overlap between species of sharks has rarely been determined; however, these findings are supported by the 2 comparative feeding ecology studies that examined elasmobranch diet by size. Ellis et al. (1996) examined the diets of 6 species of shark (from 4 families) and 4 species of rajid ray in the northeastern Atlantic Ocean and found diet overlap to be higher between species of similar size and morphology. Platell et al. (1998) examined diet overlap between 4 Australian stingarees (Urolophidae) and concluded that highest dietary overlap occurred between similar size classes of species.

\section{Habitat overlap}

Within the sampling area, there are no clear microhabitats available for juvenile shark species (e.g. seagrass beds, sand flats, or tidal lagoons). Benthic habitat on the gulf-side of St. Vincent Island is generally uniform and characterized by a mix of clay, sand, and mud over a limestone bottom (Livingston 1984). For this study, habitat overlap is calculated using proportions of a gillnet set as the resource state. Looking at habitat overlap in this manner provides a snapshot of resource overlap in time and space and tests hypotheses regarding sharks species in the same place at the same time.

Shark species-life stages showed low habitat overlap on the spatial and temporal scale of a gillnet set. It is unknown how these results compare to other elasmobranch assemblages because no other studies have examined habitat overlap between different species of sharks at the same time. Low habitat overlap values could result from sharks using separate areas or using the same area at different times. Catch data suggests young-of-the-year Atlantic sharpnose sharks recruit over a short duration from offshore pupping areas in April to inshore, protected bays in May and June. Of the 201 young-of-the-year Atlantic sharpnose sharks collected for this study, 179 of those were collected in May 2002. Of those 179, 161 were collected in one particular gillnet set on 30 May 2002. The infrequent catch or absence of young-of-the-year Atlantic sharpnose sharks from all other gillnet sets made in Apalachicola Bay, Florida, throughout the season could be an indication that this smaller species-life stage uses the gulf side of St. Vincent Island for a very short period of time, preferring the inner areas of the bay for protection from predators until reaching a larger size. The frequent catch of young-of-the-year Atlantic sharpnose sharks in gillnet sets made in other protected, shallow bays may provide more evidence that this species-life stage prefers a more enclosed habitat (Carlson \& Brusher 1999).

Like diet overlap, the degree of habitat overlap may also be dependent on size of the different species-life stages. Juvenile blacktip, finetooth, and spinner sharks in Apalachicola Bay had borderline habitat overlap across all months. Young-of-the-year Atlantic sharpnose sharks had borderline to low habitat overlap with all other species-life stages. Tiger sharks Galeocerdo cuvier have also been shown to segregate by size; juvenile tiger sharks are nocturnal, bottom-feeders while adults feed both at the surface during the day and at the bottom at night (Lowe et al. 1996).

There are 2 main restrictions to the habitat overlap analysis performed in this study. First, the majority of sampling was done between 08:00 and 17:00 h, causing habitat overlap at other times during the diel cycle to be missed. Three $24 \mathrm{~h}$ sampling trips were attempted in 2002, but because of inclement weather, only 1 trip was successful in sampling throughout the entire diel cycle. On 13 June, blacktip and finetooth made up $74 \%$ of the target species catch during the day and Atlantic sharpnose made up $100 \%$ of the target species catch at night. Spinner sharks were not caught on this date. These results are preliminary and more nocturnal sampling needs to be done to confirm use of the same areas by different species at different times over the diel cycle.

The second caveat to the habitat analysis is that the sampling was restricted to the gulf-side of St. Vincent Island, but sharks could also be using habitat inside Apalachicola Bay. The occurrence of angiosperms in shark stomachs may be an indication that these early life stages are moving into and out of the bay. Submerged vegetation is located on the bayside of St. George Island and at the mouth of the Apalachicola River (Apalachicola Bay Benthic Mapping, Protected 
Areas Geographic Information System [PAGIS] project, www.csc.noaa.gov/pagis/html/apa_act.htm). Leopard sharks Triakis semifasciata in Tomales Bay, California, have been shown to move toward the inner bay with the incoming tide and toward the outer bay with the outgoing tide, also showing greater movement at night compared to day (Ackerman et al. 2000). In the future, ultrasonic telemetry techniques (see Sundström et al. 2001 and references therein) should be used to determine activity space and habitat use of these shark species on a finer scale.

\section{Prey size analysis}

Studies on teleost piscivores have shown that they select for small-sized prey (Juanes 1994). Size-selective feeding has not been well studied for shark species. Among sharks that generally feed on benthic invertebrates, Cortés et al. (1996) found that bonnethead sharks Sphyrna tiburo in the southeast Gulf of Mexico preyed mainly upon relatively small-sized blue crab Callinectes sapidus. Although no size-selectivity analysis was performed, Heupel \& Hueter (2002) concluded that types and sizes of teleosts collected using fish traps were representative of prey types and sizes found in blacktip shark stomachs in Terra Ceia Bay, Florida. In this study, the only negative size-selection found was for Atlantic sharpnose shark feeding on Micropogonias undulatus. Negative size selectivity was not found in any other comparison.

While the absolute prey size consumed by Atlantic sharpnose and blacktip sharks increased significantly with increasing shark size, the range of absolute prey only increased slightly. Scharf et al. (2000) found that the range in absolute prey sizes increased dramatically with increasing predator size for 18 of the piscivorous marine predators they examined, 4 of which were elasmobranchs. Ontogenetic changes in median prey size eaten by Atlantic sharpnose and blacktip sharks were due to increases in maximum and minimum prey size consumed. At comparable sizes throughout their life stages, blacktip sharks are capable of taking larger prey than Atlantic sharpnose sharks. This could be an indication that blacktip shark gape size is larger than Atlantic sharpnose shark or that blacktip sharks are simply better at capturing larger, faster prey. Gape measurements were initially attempted in this study, but were not pursued due to difficulty and variability in measurement (i.e. sacrificed sharks became rigid quickly).

Diets of elasmobranchs studied here consist of relatively small prey. Scharf et al. (2000) found that over $75 \%$ of the elasmobranch diets examined consisted of prey that was less than $20 \%$ of their length. Frequency distributions of prey size-predator size ratios for Atlantic sharpnose and finetooth sharks compare well with ratio distributions for elasmobranchs in Scharf et al. (2000); however, prey size-predator size ratios for blacktip sharks do not. Blacktip sharks compare well with teleost predators from Scharf et al. (2000) that take considerable amounts of intermediate-sized prey while still feeding on small-sized prey (e.g. pollock Pollachius virens, and windowpane flounder Scophthalmus aquosus).

Scharf et al. (2000) found that ontogenetic trophic niche breadth decreased for large predators (>500 mm). Trophic niche breadth decreased as Atlantic sharpnose sharks increased in size, but remained relatively constant as blacktip sharks increased in size. The lack of a decrease in trophic niche breadth in blacktip sharks may be due the differences in species foraging habits and/or swimming ability. Blacktip sharks have been observed breaching the surface to chase prey (J. K. Carlson \& D. M. Bethea, NMFS PC Laboratory, pers. obs.).

A caveat to prey size analysis in this study was the inability to catch all available prey sizes due to sizeselective gear bias. Three types of sampling gear (larger-meshed gillnet, smaller-meshed gillnet, and otter trawl) were used to control for gear bias; however, the gear were not always used at the same time and/or not used for the entire study period. For future research, sampling methods that capture all prey types and sizes available should be used simultaneously and throughout the study period.

\section{CONCLUSIONS}

Are these sharks competing for available resources? Similar-sized species-life stages had moderate diet overlap. As a highly productive estuary (Livingston \& Joyce 1977, Livingston 1983), it could be that food resources (e.g. Brevoortia spp.) are not limiting in the Apalachicola Bay system. However, if diet resources are limited, using different resource axes such as space or time could reduce competition pressure between shark species. Evidence for this is provided by the observed low habitat overlap. More intensive and finer-scale monitoring, such as diel gillnet sampling (both inside and outside the bay) and the use of telemetry, is needed to fully understand temporal and spatial habitat use patterns among these early life stages.

In addition to quantifying resource overlap within one nursery area, comparing growth rates of sharks among several proposed nursery areas with different shark assemblages could be used to test for competition. A species-life stage with a relatively low growth 
rate in one nursery may be experiencing higher competition for available resources compared to that same species with a relatively higher growth rate in another nursery. When fed a diet of teleosts in the laboratory, young-of-the-year Atlantic sharpnose sharks grew almost 3 times as fast than when fed a diet of crustaceans (T. Lankford \& N. Sanscrainte, University of North Carolina Wilmington, pers. comm.). Stomach contents of Atlantic sharpnose sharks from other nursery areas should be examined for differences in diet. In other nursery areas, young-of-the-year Atlantic sharpnose sharks may feed more on teleosts and less on crustaceans due to a decrease in competition for teleost resources (and/or decreased threat of predators).

The development of Fisheries Ecosystem Plans, management plans that require the consideration of all biotic, abiotic, and human-related interactions with the target stock, have been recommended (NMFS 1999b); however, predator-prey relationships for early life stages of many sharks remain relatively unknown (NMFS 1999a). The prey of Atlantic sharpnose, blacktip, finetooth, and spinner sharks that are also important resource species in this area include menhaden, Atlantic croaker, and shrimp. Quantifying the links among these sharks and the links between these sharks and resource species are critical for ecosystem modeling and a key step to a broader approach in fisheries management.

Acknowledgements. We thank the staff and personnel of the NOAA National Marine Fisheries Service Panama City Laboratory in Panama City Beach, FL, the Zoology Department at North Carolina State University in Raleigh, NC, and the Center for Marine Sciences \& Technology in Morehead City, NC, for assistance throughout this project. This project would not have been possible without the hard work of: I. Baremore, L. Damange, C. Flora, L. Hale, S. Sherril-Mix, M. Satterwhite, and J. Smith. Special thanks go to P. Rand, J. Osborne, and 3 anonymous referees for critical reviews of the manuscript and F. Scharf for several discussions concerning quantile regression analysis. T. Tuckey at the Florida Marine Research Institute Apalachicola Field Laboratory, Eastpoint, FL, provided additional prey abundance data. The trawl was borrowed from B. Thompson in the Coastal Fisheries Institute at Louisiana State University. Opinions expressed herein are of the authors only. Reference to trade names does not imply endorsement by the NOAA/National Marine Fisheries Service.

\section{LITERATURE CITED}

Ackerman JT, Kondratieff MC, Matern SA Jr, Cech JJ (2000) Tidal influence on spatial dynamics of leopard sharks, Triakis semifasciata, in Tomales Bay, California. Environ Biol Fish 58:33-43

Barry KP (2002) Feeding habits of blacktip sharks, Carcharhinus limbatus, and Atlantic sharpnose sharks, Rhizoprionodon terraenovae, in Louisiana coastal waters. MS thesis, Louisiana State University, Baton Rouge, LA
Branstetter S (1990) Early life-history implications of selected carcharhinoid and lamniod sharks of the northwest Atlantic. NOAA (Natl Ocean Atmos Adm) Tech Rep NMFS 90:17-28

Buckel JA, Fogarty MJ, Conover DO (1999) Foraging habits of bluefish, Pomatomus saltatrix, on the US east coast continental shelf. Fish Bull 97:758-775

Carlson JK, Brusher JH (1999) An index of abundance for coastal species of juvenile sharks from the northeast Gulf of Mexico. Mar Fish Rev 61:37-45

Castro JI (1993) The biology of the finetooth shark Carcharhinus isodon. Environ Biol Fish 36:219-232

Cortés E (1997) A critical review of methods of studying fish feeding based on analysis of stomach contents: application to elasmobranch fishes. Can J Fish Aquat Sci 54: $726-738$

Cortés E (1999) Standardized diet compositions and trophic levels of sharks. ICES J Mar Sci 56:707-717

Cortés E, Gruber SH (1990) Diet, feeding habits and estimates of daily ration of young lemon sharks, Negaprion brevirostris (Poey). Copeia 1:204-218

Cortés E, Manire CA, Hueter RE (1996) Diet, feeding habits, and diel feeding chronology of the bonnethead shark, Sphyrna tiburo, in southwest Florida. Bull Mar Sci 58: 353-367

Ebert DA (2002) Ontogenetic changes in the diet of the sevengill shark (Notorhynchus cepedianus). Mar Freshw Res 53:517-523

Ellis JR, Pawson MG, Shackley SE (1996) The comparative feeding ecology of 6 species of sharks and 4 species of ray (Elasmobranchii) in the northeast Atlantic. J Mar Biol Assoc UK 76:89-106

Ferry LA, Cailliet GM (1996) Sample size and data: Are we characterizing and comparing diet properly? In: Mackinlay D, Shearer K (eds) Feeding ecology and nutrition in fish. Proceedings of the Symposium on the Feeding Ecology and Nutrition in Fish, International Congress on the Biology of Fishes, San Francisco, California. American Fisheries Society, San Francisco, CA, p 70-81

Gelsleichter J, Musick JA, Nichols S (1999) Food habits of the smooth dogfish, Mutelus canis, dusky shark, Carcharhinus obscurus, Atlantic sharpnose shark, Rhizoprionodon terraenovae, and the sand tiger shark, Carcharias taurus, from the northwest Atlantic Ocean. Environ Biol Fish 54: 205-217

Heupel MR, Hueter RE (2002) Importance of prey density in relation to the movement patterns of juvenile blacktip sharks (Carcharhinus limbatus) within a coastal nursery area. Mar Freshw Res 53:543-550

Heupel MR, Simpfendorfer CA (2002) Estimation of mortality of juvenile blacktip sharks, Carcharhinus limbatus, within a nursery area using telemetry data. Can J Fish Aquat Sci 59:624-632

Jennings S, Kaiser MJ (1998) The effects of fishing on marine ecosystems. Adv Mar Biol 34:201-352

Jobling M, Breiby A (1986) The use and abuse of fish otoliths in studies of feeding habits of marine piscivores. Sarsia 71: 265-274

Juanes F (1994) What determines prey size selectivity in piscivorous fishes? In: Stouder DJ, Fresh KL, Feller RJ (eds) Theory and application in fish feeding ecology. Belle W. Baruch Library in Marine Sciences, No. 18, University of South Carolina Press, Columbia, SC, p 79-100

Livingston RJ (1983) Resource atlas of the Apalachicola estuary. Florida Sea Grant Publication, Gainesville, FL

Livingston RJ (1984) The ecology of the Apalachicola Bay system: an estuarine profile. US Department of the Interior, 
Fish and Wildlife Service, Washington, DC, FWS/OBS $82 / 05$

Livingston RJ, Joyce EA (eds) (1977) Proceedings of the conference on the Apalachicola drainage system, Gainesville, Florida. Fla Mar Res Publ 26:75-100

Lowe CG, Wetherbee BM, Crow GL, Tester AL (1996) Ontogenetic dietary shift and feeding behavior of the tiger shark, Galeocerdo cuvier, in Hawaiian waters. Environ Biol Fish 47:203-211

National Marine Fisheries Service (NMFS) (1999a) Fishery management plan of the Atlantic tunas, swordfish and sharks. National Oceanic and Atmospheric Administration, US Department of Commerce, Washington, DC

National Marine Fisheries Service (NMFS) (1999b) Ecosystem-based fishery management: a report to Congress by the Ecosystems Principles Advisory Panel. National Oceanic and Atmospheric Administration, US Department of Commerce, Washington, DC

Pianka ER (1976) Competition and niche theory. In: May RM (ed) Theoretical ecology: principles and applications. WD Saunders, Philadelphia, PA, p 114-141

Platell ME, Potter IC, Clarke RR (1998) Resource partitioning by 4 species of elasmobranchs (Batoidae: Urolophidae) in coastal waters of temperate Australia. Mar Biol 131: 719-734

Popova OA (1978) The role of predaceous fish in ecosystems. In: Gerking SD (ed) Ecology of freshwater fish production. John Wiley \& Sons, New York, p 215-249

Pratt HL Jr (1988) Elasmobranch gonad structure: a description and survey. Copeia 3:719-729

Scharf FS, Juanes F, Roundtree RA (2000) Predator-prey relationships of marine fish predators: interspecific variation and effects of ontogeny and body size on trophic-niche breadth. Mar Ecol Prog Ser 208:229-248

Editorial responsibility: Otto Kinne (Editor), Oldendorf/Luhe, Germany
Schindler DE, Essington TE, Kitchell JF, Boggs C, Hilborn R (2002) Sharks and tunas: fisheries impacts on predators with contrasting life histories. Ecol Appl 12:735-748

Simpfendorfer CA, Milward NE (1993) Utilization of a tropical bay as a nursery area by sharks of the families Carcharhinidae and Sphyrnidae. Environ Biol Fish 37: 337-345

Simpfendorfer CA, Goodreid A, McAuley RB (2001) Diet of three commercially important shark species from Western Australian waters. Mar Freshw Res 52:975-985

Stevens JD, McLoughlin KJ (1991) Distribution, size, and sex composition, reproductive biology and diet of sharks from northern Australia. Aust J Mar Freshw Res 40:129-146

Stevens JD, Bonfil R, Dulvy NK, Walker PA (2000) The effects of fishing on sharks, rays, and chimeras (chondrichthyans), and the implications for marine ecosystems. ICES J Mar Sci 57:476-494

Sundström LF, Gruber SH, Clermont SM, Correia JPS and 5 others (2001) Review of elasmobranch behavioral studies using ultrasonic telemetry with special reference to the lemon shark, Negaprion brevirostris, around Bimini Islands, Bahamas. Environ Biol Fish 60:225-250

Wetherbee BM, Crowe GL, Lowe CG (1996) Biology of the Galapagos shark, Carcharhinus galapagensis, in Hawaii. Environ Biol Fish 45:299-310

Winemiller KO, Pianka ER (1990) Organization and natural assemblages of desert lizards and tropical fishes. Ecol Monogr 60:27-55

Yamaguchi A, Taniuchi T (2000) Food variations and ontogenetic dietary shift of the starspotted-dogfish Mustelus manazo at 5 locations in Japan and Taiwan. Fish Sci 66: 1039-1048

Zar JH (1999) Biostatistical analysis, 4th edn. Prentice-Hall, Upper Saddle River, NJ

Submitted: July 14, 2003; Accepted: November 11, 2003 Proofs received from author(s): February 23, 2004 